\title{
Second-Generation Antipsychotics and Dysregulation of Glucose Metabolism: Beyond Weight Gain
}

\author{
Diana Grajales ${ }^{1,2} \mathbb{D}$, Vitor Ferreira ${ }^{1,2}$ and Ángela M. Valverde ${ }^{1,2, *}$ \\ 1 Instituto de Investigaciones Biomédicas Alberto Sols (CSIC-UAM), 28029 Madrid, Spain; \\ dgrajales@iib.uam.es (D.G.); vdasilva@iib.uam.es (V.F.) \\ 2 CIBER de Diabetes y Enfermedades Metabólicas Asociadas (CIBERDEM), ISCIII, 28029 Madrid, Spain \\ * Correspondence: avalverde@iib.uam.es; Tel.: +34-91-5854497; Fax: +34-91-5854401
}

Received: 10 October 2019; Accepted: 26 October 2019; Published: 29 October 2019

\begin{abstract}
Second-generation antipsychotics (SGAs) are the cornerstone of treatment for schizophrenia because of their high clinical efficacy. However, SGA treatment is associated with severe metabolic alterations and body weight gain, which can increase the risk of type 2 diabetes and cardiovascular disease, and greatly accelerate mortality. Several underlying mechanisms have been proposed for antipsychotic-induced weight gain (AIWG), but some studies suggest that metabolic changes in insulin-sensitive tissues can be triggered before the onset of AIWG. In this review, we give an outlook on current research about the metabolic disturbances provoked by SGAs, with a particular focus on whole-body glucose homeostasis disturbances induced independently of AIWG, lipid dysregulation or adipose tissue disturbances. Specifically, we discuss the mechanistic insights gleamed from cellular and preclinical animal studies that have reported on the impact of SGAs on insulin signaling, endogenous glucose production, glucose uptake and insulin secretion in the liver, skeletal muscle and the endocrine pancreas. Finally, we discuss some of the genetic and epigenetic changes that might explain the different susceptibilities of SGA-treated patients to the metabolic side-effects of antipsychotics.
\end{abstract}

Keywords: antipsychotics; second-generation antipsychotics; glucose dysregulation; insulin resistance; insulin secretion; metabolic side-effects; schizophrenia; type 2 diabetes

\section{Introduction}

1.1. Antipsychotic Treatment for Schizophrenia and Other Mental Illnesses: First-Versus Second-Generation Antipsychotics

Antipsychotic drugs (APDs) are the cornerstone of treatment for schizophrenia and other mental diseases, including bipolar disorders, dementia, autism-related irritability and severe mental illness [1-3]. Since the release of the first antipsychotic — chlorpromazine—in 1952, which was originally synthesized as an anesthetic adjunct, pharmacotherapy has been the mainstay treatment for psychotic disorders [4]. The clinical success of chlorpromazine for treating schizophrenia stimulated the widespread synthesis of chlorpromazine-related compounds, leading to the later development of the so-called first-generation antipsychotics (FGAs) (also known as typical antipsychotics) such as fluphenazine and haloperidol, whose common features were the tricyclic chemical structure of chlorpromazine and their ability to induce catalepsy in rats [5]. However, many patients treated with FGAs had a suboptimal response and developed extrapyramidal side-effects (EPS) and severe movement disorders, such as parkisonism, dyskinesia and akathisia. These serious symptoms prompted the development of new compounds, known as second-generation (atypical) antipsychotics (SGAs), which did not produce significant EPS and preserved the efficacy for treating refractory schizophrenia [6,7]. The first of these SGAs was clozapine, 
which was introduced in the mid-1970s, and was followed by risperidone, olanzapine, ziprasidone, quetiapine, amisulpride, sertindole, lurasidone, paliperidone, iloperidone, asenapine and, more recently, aripiprazole [8]. The APDs have in common their antagonism of the D2 dopamine receptor (D2R) with the exception of aripiprazole, which acts as a partial agonist [9]. It has been estimated that APDs show optimal efficacy when their D2R occupancy is 60-70\%, and D2R occupancy levels higher than $80 \%$ frequently induce EPS. Because SGAs maintain a threshold of $65-80 \%$ D2R occupancy, their use minimizes the risk of EPS while achieving optimal antipsychotic efficacy [10-13]. The elevated D2R occupancy of some FGAs (such as haloperidol) was recently reported to result from their fast association rate and high potential of rebinding, whereas the slower association rate and lower rebinding potential of SGAs reduce D2R occupancy [14].

In contrast to the exclusively high affinity binding of FGAs to D2R, SGAs exert their action by engaging with a broader range of receptors, including dopamine (D1R, D2R and D4R), serotonin (5- $\mathrm{HT}_{1} \mathrm{~A}, 5-\mathrm{HT}_{2} \mathrm{~A}, 5-\mathrm{HT}_{2} \mathrm{C}, 5-\mathrm{HT}_{6}, 5-\mathrm{HT}_{7}$ ), histamine (H1R) and muscarinic (M3R) receptors $[15,16]$. In addition to the reduction in D2R occupancy, the lower liability of EPS with SGAs can be explained by their antagonism or inverse agonism of the serotonin $5-\mathrm{HT}_{2} \mathrm{~A}$ receptor, which can increase dopaminergic transmission in the nigrostriatal pathway (impeding the development of motor disorders), and agonism of $5-\mathrm{HT}_{1} \mathrm{~A}$ in the mesocortical pathway, which facilitates dopamine release in the prefrontal cortex and hippocampus [17]. Overall, the switch from exclusively D2R antagonism of FGAs to redesigned SGAs, which have a more diverse receptor binding profile, has improved the negative symptoms (including EPS) and the tolerability in patients and, hence, SGAs are extensively prescribed as the first-line of treatment for schizophrenia.

\subsection{Are the Metabolic-Side Effects in Patients with Severe Mental Illness Due to Schizophrenia, SGAs or Other} Factors?

It has been estimated that the lifespan of patients with severe mental illness is reduced by 10-20 years compared with the healthy population [18], with cardiovascular disease being the leading cause of death in people with schizophrenia [19-21]. In fact, patients with schizophrenia are at three-fold higher risk of obesity and two- to four-fold higher risk of type 2 diabetes mellitus (T2D), which are common causes of cardiovascular disease [22]. Several factors are involved in the increased risk of cardiovascular disease in this population, including higher rates of smoking [23], unhealthy diet and reduced physical exercise [24,25], low-income [26] and the antipsychotic treatment itself, particularly SGAs [27]. Indeed, it is now recognized that despite their clinical efficacy in treating psychiatric disorders and reducing motor side-effects over FGAs, SGAs are associated with severe metabolic alterations such as weight gain, hyperphagia, hyperglycemia, insulin resistance, dyslipidemia, and T2D development-all common features of the metabolic syndrome (MetS) and major risk factors for cardiovascular disease [28].

The possibility that severe mental illness, and especially schizophrenia, is independently associated with the development of MetS and cardiovascular disease, has been investigated in several studies, with results showing that first-episode, drug-naïve patients with schizophrenia have increased plasma insulin levels [29,30], elevated fasting glucose [31], impaired glucose tolerance [32], and changes in lipid metabolism [28]. Given these findings, the possibility of a genetic predisposition to both T2D/weight gain and schizophrenia has been examined; however, results so far have been inconclusive mainly because of the polygenic contribution to both diseases, which challenges the identification of allelic risk variants. Nevertheless, some candidate genes associated with T2D and schizophrenia have been proposed, including phosphatidylinositol 3-kinase regulatory subunit alpha (PIK31), an upstream activator of protein kinase $B$ (AKT) signaling; calcium-dependent mediators such as protein kinase $\mathrm{C}$ alpha (PRKCA) and protein kinase, DNA-activated, catalytic subunit (PRKAC); non-receptor type 11 protein tyrosine phosphatase (PTPN11) [33], which is involved in adipokine signaling; protein tyrosine phosphatase receptor type D (PTPRD) [34]; and low-density lipoprotein receptor-related 
protein (LRP4) [35]. Yet, other studies have not found a clear pathogenetic association between the two diseases [36,37].

There is much stronger evidence directly linking SGA medication to increased risk of T2D in patients with schizophrenia. In fact, is well known that the pediatric population is especially susceptible to the metabolic side-effects of SGAs [38,39]. In a study in young patients [38], first-time use of olanzapine, risperidone, aripiprazole or quetiapine induced the transition from normal weight to overweight/obese status in 10-36\% of individuals after only 12 weeks of treatment, with olanzapine inducing the strongest effects on body weight gain. Similarly, the European first-episode schizophrenia trial study (EUFEST) reported that whereas the prevalence of MetS was similar between young antipsychotic-naïve patients with schizophrenia and the normal population, a worsening of glucose levels leading to hyperglycemia was noted in those patients treated with amisulpride, olanzapine or ziprasidone for 52 weeks [27]. This is in line with the evidence of a recent large-scale systematic review and meta-analysis [25] that found a prevalence of only $2.9 \%$ of T2D in antipsychotic-naïve patients and $11.3 \%$ in patients with severe mental illness medicated with SGAs, with the highest prevalence associated with clozapine and olanzapine. A recent nationwide Danish study also reported a significant relationship between exposure to SGAs and diabetic ketoacidosis, caused by insulin deficiency [40]. In another Danish cohort, olanzapine and aripiprazole were shown to increase the rate of T2D in patients with schizophrenia by almost two-fold, whereas clozapine increased the rate four-fold [41]. Of note, the association between aripiprazole (which acts as a partial agonist of D2R) and metabolic-side effects remains unclear, as some studies have found a lower risk for T2D in patients treated with this drug [25,42]. Moreover, it has been shown that genetic polymorphisms can influence the pharmacokinetics of SGAs. For example, polymorphisms in P-glycoprotein, a drug efflux pump, impact the pharmacokinetics of SGAs and, consequently, how patients respond to pharmacotherapy [43].

While FGAs were not initially linked to metabolic side-effects, some studies indicate that both FGAs and SGAs increase the risk for T2D. In a large Danish cohort study (7139 subjects) first-episode, drug-naïve patients with schizophrenia receiving the FGAs chlorpromazine, levomepromazine or chlorprothixene had an elevated risk for T2D, although the highest risk was found in patients prescribed the SGAs olanzapine or clozapine [42]. In a similar line, a significant increase in body-mass index was reported in South African first-episode, drug-naïve patients with schizophrenia treated for 12 months with long-acting injectable flupenthixol, and this was accompanied by increased triglyceride and decreased high-density lipoprotein levels [44]. Nevertheless, as mentioned above, the majority of studies comparing FGAs versus SGAs report that metabolic abnormalities are more common in patients prescribed the latter $[45,46]$. Furthermore, it is generally accepted that the pediatric and female populations are more susceptible to the metabolic side-effects of SGAs [47].

Unraveling the association between severe mental illness, SGAs and T2D is a challenging endeavor, as most epidemiological studies have limitations. The inability to adjust for confounding factors such as age, sex, specific treatment (posology and duration), previous treatment/s or switch of medication, onset and severity of severe mental illness, variation in the sample size, lifestyle, and socio-economic factors, can all have an impact on outcomes. Moreover, each SGA can have a different metabolic risk profile independently of its class and, in this regard, it is perhaps more valuable to assess the individual risk of each drug rather than focusing on the collective metabolic side-effects of one class or the other. Overall, even if a schizophrenia-related locus can confer an increased risk for MetS, this susceptibility is further bolstered by APD medication, primarily SGAs, with variable and complex metabolic side-effects and diabetogenic properties (Figure 1). 
Olanzapine

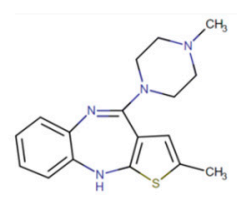

Risperidone

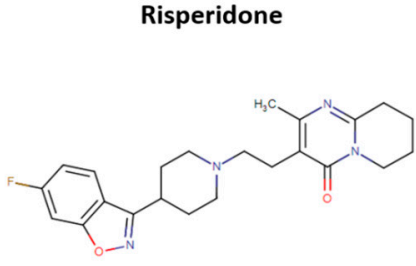

Amisulpride

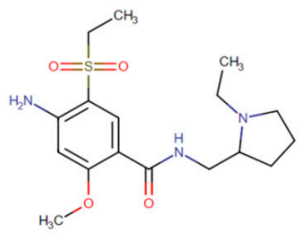

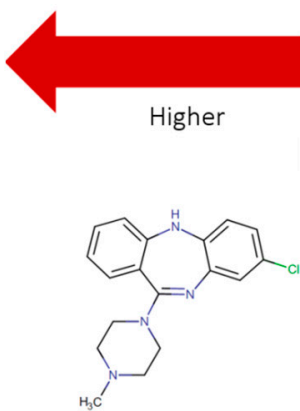

Clozapine

Type 2 Diabetes risk

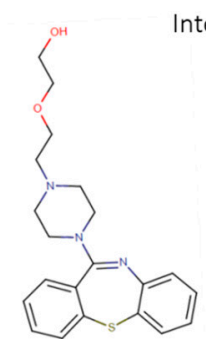

Quetiapine
Intermediate

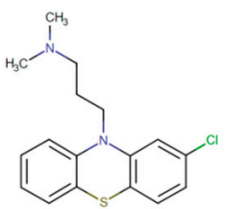

Chlorpromazine
Lower

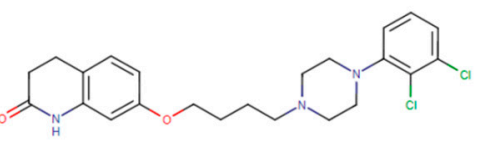

Aripiprazole

Figure 1. Scheme of antipsychotic drugs (APDS) commonly associated with diabetogenic properties. First-generation antipsychotic (FGA) = chlorpromazine; Second-generation antipsychotics (SGAs) = olanzapine, clozapine, quetiapine, risperidone, amisulpride and aripiprazole.

1.3. Elucidation of SGAs Effects on Glucose Tolerance, Insulin Resistance and Body Weight Gain: Acute Studies with Healthy Volunteers

While accumulating evidence has linked SGAs therapy to metabolic disturbances, understanding the mechanistic bases of these side-effects remains challenging as the bulk of research is conducted in patients under chronic treatment. Accordingly, short-term administration of SGAs in healthy volunteers is commonly performed to examine the primary metabolic side-effects independently of the secondary effects triggered by T2D and obesity, as well as other disturbances.

Since olanzapine and clozapine appear to induce the most severe metabolic abnormalities, they are, understandably, the focus of the bulk of studies in healthy volunteers. In this regard, acute effects of these drugs on glucose tolerance ( $\leq 14$ days) have been evaluated in several studies. For example, in an open-label study, healthy volunteers with no family history of inherited T2D, fasting glucose levels $\leq 100 \mathrm{mg} / \mathrm{dL}$ and normal body-mass index $\left(18-25 \mathrm{~kg} / \mathrm{m}^{2}\right)$ were randomized to receive olanzapine (10 $\mathrm{mg} / \mathrm{d}$ ) or ziprasidone $(80 \mathrm{mg} / \mathrm{d})$ for 10 days, and were then subjected to hyperinsulinemic-euglycemic clamp (HEC) analysis, which measures insulin action in vivo. Olanzapine was found to reduce glucose uptake and increase plasma insulin levels compared with baseline levels, whereas ziprasidone failed to cause acute changes in glucose tolerance [48]. In another study in healthy subjects without psychiatric history and with normal body-mass index, olanzapine or aripiprazole $(10 \mathrm{mg} / \mathrm{d})$ were administered for 9 days and insulin sensitivity was evaluated after conducting a meal challenge before and after HEC analysis [49]. Olanzapine induced postprandial hyperinsulinemia in 9 out of 10 subjects, accompanied by a small elevation in glucagon levels and, surprisingly, an increase in GLP-1 levels, which are normally reduced in T2D. Similar to olanzapine, aripiprazole decreased the C-peptide/insulin ratio, considered as an index of hepatic insulin clearance and insulin resistance. No changes in body weight were reported in individuals receiving either of the SGAs, suggesting that metabolic changes in insulin-sensitive tissues are triggered before body weight gain. The rapidly induced metabolic effects of olanzapine have also been reported with regard to lipid metabolism, as only a 3-day treatment $(10 \mathrm{mg} / \mathrm{d})$ in healthy volunteers increased circulating leptin and triglycerides levels, typically elevated in T2D [50]. However, individuals have a different susceptibility to SGA-induced metabolic side-effects. For instance, in a study of healthy male volunteers, mild treatment with 
olanzapine over two weeks ( $5 \mathrm{mg} / \mathrm{d}$ for the first 7 days and $10 \mathrm{mg} / \mathrm{d}$ for the next 7 days) led to weight gain in only two-thirds of volunteers. Nevertheless, all volunteers showed a significant increase in circulating insulin, triglycerides and leptin, but only the weight-gain group showed changes in glucose, low-density lipoprotein and total cholesterol levels [51]. A meta-analysis of healthy volunteers' studies showed that weight gain is typically found in treatments lasting longer than 14 days, clearly associating body weight gain with the length of the treatment, whereas insulin sensitivity is more closely associated with the SGA used [52]. In this regard, a cross-sectional analysis of more than 3000 articles published on antipsychotic-induced weight gain (AIWG) in first-episode, drug-naïve patients with schizophrenia found an average increase of $5.3 \mathrm{~kg}$ in weight and $1.86 \mathrm{~kg} / \mathrm{m}^{2}$ in body-mass index in SGA-treated patients compared with patients receiving placebo in treatments longer than 12 weeks; the highest weight gain was found with olanzapine and clozapine, followed by quetiapine and risperidone. This meta-analysis also found that aripiprazole, often associated with fewer metabolic side-effects, led to weight gain after short-term periods of treatment [53].

Despite this review focuses on SGAs-mediated glucose dysregulation independently of body weight gain, it is noteworthy to mention that both AIWG and dyslipidemia are major metabolic side-effects $[28,50,51]$. AIWG results from the imbalance between energy intake and energy expenditure and the variety of receptors that SGAs target suggest that AIWG is a multifactorial phenomenon. While the mechanisms behind reduction in energy expenditure are not fully understood [54], meta-analysis studies have correlated the ability of SGAs to target neurotransmitter receptors in the central nervous system (CNS) with increased food intake. The more relevant include blockade of hypothalamic H1R [55], different polymorphisms in serotonin receptor 5- $\mathrm{HT}_{2} \mathrm{C}$ [56,57], that interfere with satiety and appetite centers, and blockade of D2R receptors [58] which might hamper the normal functioning of reward-related behaviors, also explaining the weight gain susceptibility observed in SGAs-treated patients. Dyslipidemia, on the other hand, is commonly manifested as an increase in total triglyceride and decrease of high-density lipoprotein levels. It is well known that the liver converts the excess of exogenous glucose into triglycerides. Triglycerides are then packaged into low-density lipoproteins and transported to the adipose tissue for long-term energy storage [59]. Therefore, as we will discuss in the following sections, the ability of SGAs to increase blood glucose levels and induce insulin resistance can also misbalance triglyceride metabolism and cause dyslipidemia. On the other hand, increased cholesterol levels could be due to a direct effect of SGAs in lipid metabolism independently of changes in glucose metabolism, as these drugs up-regulate sterol regulatory element binding protein-2 (SREBP-2) [60,61], the master regulator of cholesterol biosynthesis.

Overall, studies in healthy volunteers link SGAs to body weight gain, but also to impairment in glucose metabolism independently of AIWG, the main subject of this review. However, the short duration of the clinical trials might underpower the link between SGAs and T2D, since T2D development occurs over many years. Despite this limitation, studies with healthy volunteers have contributed significantly to address the sub-acute metabolic effects of SGAs and their diabetogenic properties, which might predict the outcome of chronic long-term treatment with these drugs in patients.

\section{New Insights into the Molecular Mechanisms by which SGAs Disrupt Whole-Body Glucose Homeostasis: From Cellular and Animal Models to Humans}

It was initially believed that glucose dysregulation linked to SGAs results from AIWG, but it is now accepted that glucose metabolism is dysregulated even in the absence of weight gain. Therefore, this review is based on the dysregulation of glucose homeostasis by SGAs independently of body weight gain and changes in lipid metabolism/adipose tissue function, focusing on the molecular alterations triggered by SGAs in liver, skeletal muscle and endocrine pancreas. In this regard, as we will discuss below, cellular and preclinical animal models have provided valuable knowledge about the main targets and molecular pathways disrupted by SGAs (for instance, the intracellular insulin signaling pathways) that can predict long-term metabolic outcomes. 


\subsection{Cellular Studies Addressing Dysregulation of Glucose Homeostasis by SGAs}

Mechanistic insights into the cell-autonomous signaling pathways targeted by SGAs have been gained using in vitro studies. An important caveat in translating these results to a pathophysiological in vivo context, however, is the difference between the therapeutic plasma levels found in patients and the doses used in vitro. For instance, the therapeutic plasma levels of olanzapine and clozapine are approximately 0.3 to $3 \mu \mathrm{M}$ respectively [62], whereas the concentrations used in vitro normally range between 1 and $100 \mu \mathrm{M}$. That being said, it has been reported that the concentration of SGAs in rodent tissues could be 20-100-fold higher than those in plasma [63,64].

\subsubsection{SGA-Mediated Molecular Alterations in Glucose Metabolism in Hepatocytes: In Vitro Studies}

Hepatocytes play a critical role in glucose homeostasis by regulating glycolysis, gluconeogenesis, glucose uptake and glycogen synthesis [65]. However, very little is currently known about the impact of SGAs on the molecular machinery that governs glucose metabolism in hepatic cells.

Hepatic glycogen and triglycerides are the two long-term sources of energy storage in the body. Glycogen accumulates in the liver in response to insulin and is hydrolyzed to glucose in response to glucagon, ensuring the balance in overall glucose homeostasis. Hepatic glycogen synthesis is regulated by glucokinase and glycogen phosphorylase. Activation of glucokinase increases the flux of glucose towards glycolysis and glycogen synthesis, whereas inactivation of glycogen phosphorylase stimulates glycogen storage. Serotonin signaling is known to exert both stimulatory (via $5-\mathrm{HT}_{1} \mathrm{~A} / 5-\mathrm{HT}_{2} \mathrm{~A}$ receptors) and inhibitory (via 5- $\mathrm{HT}_{2} \mathrm{~B}$ receptors) effects on hepatic glycogen synthesis, with the stimulatory action dominating. This was elegantly elucidated by Tudhope and collaborators [66], who showed that the double $5-\mathrm{HT}_{1} / 5-\mathrm{HT}_{2}$ agonist $\alpha$-methyl-5HT, which mimics the stimulatory but not the inhibitory effects of 5-HT, increased glycogen synthesis in rat hepatocytes after $2 \mathrm{~h}$ incubation at $100 \mu \mathrm{M}$ concentration. This effect was blunted in hepatocytes co-treated with $\alpha$-methyl-5HT and olanzapine $(10-100 \mu \mathrm{M})$, which binds 5-HT receptors. In an earlier study, the same group reported that $\alpha$-methyl-5HT stimulates glycogen synthesis by inactivating glycogen phosphorylase, and showed that clozapine and olanzapine counteracted this inactivation [67]. Therefore, inhibition of glycogen synthesis in hepatocytes might be a mechanism underlying the hyperglycemia associated with both SGAs.

In addition to disrupting glucose homeostasis in hepatocytes, SGAs are also linked to hepatoxicity, but only at doses far exceeding therapeutic levels. In studies using the insulin-sensitive hepatic cell line FL-83Bm, exposure to 10-50 $\mu \mathrm{M}$ clozapine over $24 \mathrm{~h}$ increased mitochondrial membrane depolarization in a dose-dependent manner [68]. Supporting this finding, isolated rat hepatocytes were subjected to accelerated cytotoxicity mechanism screening, a technique used to assess the cytotoxicity of high doses of drugs during short-time periods and that apparently correlates with cytotoxicity of lower doses and longer periods, which revealed that both risperidone $(400 \mu \mathrm{M})[69]$ and olanzapine $(6 \mathrm{mM})$ [70] induce the production of reactive oxygen species (ROS), leading to mitochondrial dysfunction.

2.1.2. Alterations of the Insulin Signaling Pathways and Glucose Transport in Skeletal Muscle Cellular Models

Studies in skeletal muscle cells have revealed SGA-induced impairments in glycogen content, insulin signaling, and glucose transport. Similar to hepatic cells, rat L6 skeletal muscle cells treated with olanzapine $(100 \mu \mathrm{M})$ had diminished glycogen content concomitant with phosphorylation of glycogen synthase at Ser ${ }^{641}$. By contrast, amisulpride, a SGA not associated with T2D induction, failed to elicit this effect [71]. In the same study, olanzapine treatment (10 and $100 \mu \mathrm{M}$ for $72 \mathrm{~h})$ blocked insulin-stimulated insulin receptor substrate-1 (IRS-1) phosphorylation and decreased AKT and glycogen synthase kinase-3 (GSK-3 $\alpha / \beta)$ phosphorylation, reflecting an impairment of the insulin signaling cascade. Likewise, clozapine $(1.5 \mu \mathrm{M}, 24 \mathrm{~h})$ reduced insulin-induced IRS-1 tyrosine phosphorylation and AKT serine phosphorylation at $\operatorname{Ser}^{473}$ and inhibited glucose uptake [72]. In a study using mouse $\mathrm{C} 2 \mathrm{C} 12$ myoblasts, olanzapine $(20 \mu \mathrm{M}, 2 \mathrm{~h})$ failed to modulate AKT activity, both in the absence and the presence of insulin [73]; however, another study showed that it increased glucose uptake via the activation of 
adenosine 5-monophosphate-activated protein kinase (AMPK) [74], which is in contrast to the reported inhibitory actions of this antipsychotic on glucose uptake in C2C12 [75] and L6 muscle cells [72,76]. In a more recent study, quetiapine $(10-100 \mu \mathrm{M}, 1 \mathrm{~h})$ treatment decreased insulin-stimulated glucose uptake in C2C12 myotubes, an effect that could be reverted by calcitriol (0.1-10 nM), highlighting the positive effect of vitamin D in alleviating SGA-induced metabolic side-effects [77]. Likewise, ex vivo experiments in rat soleous skeletal muscle showed no effects of haloperidol, olanzapine or clozapine (1-10 $\mu \mathrm{M}, 30 \mathrm{~min})$ on glucose uptake [78]. It is relevant to mention that the impact of SGAs on the translocation of the insulin-sensitive glucose transporter (GLUT) 4 to the plasma membrane has not been studied in depth, although it was reported that olanzapine $(20 \mu \mathrm{M}, 2 \mathrm{~h})$ stimulated glucose transport in $\mathrm{C} 2 \mathrm{C} 12$ cells by increasing the abundance of GLUT4 at the plasma membrane, in a similar manner to insulin [73]. However, a recent study has shown that 5-HT induces GLUT4 translocation to the plasma membrane via serotonylation of Rab4, a small GTPase activated by the insulin-signaling pathway, suggesting that disruptors of 5-HT signaling, such as SGAs, may interfere with GLUT4 translocation and glucose transport in muscle cells [79]. This effect could be achieved by a direct interaction with GLUT4 as olanzapine can bind the Staphylococcus epidermidis glucose/ $\mathrm{H}(+)$ symporter (GlcPSE) through a residue also conserved in this glucose transporter [80].

Overall, the limited number of in vitro studies in skeletal muscle cells have linked SGAs with insulin signaling impairment, mainly by derangement of AKT phosphorylation and interference with glucose uptake and transport, although the effects may be different depending on the doses and incubation times used.

2.1.3. Impact of SGAs on Insulin Secretion and $\beta$-Cell Function: Molecular Targets in Cultured $\beta$-Cells and Pancreatic Islets

Insulin secretion is a tightly controlled process that is regulated by a number of factors including dopaminergic, serotonergic and cholinergic signaling pathways. Pancreatic $\beta$-cells express a variety of dopaminergic receptors (D1R-D2R) and can synthesize, metabolize and store dopamine inside their vesicles [81-83]. In response to high glucose, dopamine is co-released with insulin into the extracellular space where it exerts a paracrine action on the adjacent $\beta$-cells by binding to D2R and partially suppressing insulin secretion via decreasing cell membrane depolarization and calcium influx $[84,85]$. Moreover, $\beta$-cells express different serotonergic receptors and synthesize, store and release 5 -HT in response to glucose stimulation, although extracellular 5-HT may act as a stimulator or inhibitor of insulin secretion depending on the expression of the different 5-HT receptor subtypes $[86,87]$. In addition, the signaling pathways mediated by M3R in the pancreatic islets are also tightly linked to insulin secretion and $\beta$-cell function $[88,89]$. Despite these numerous investigations, the impact of SGAs on insulin secretion remains unclear and seems to depend on the dose and treatment time, as well as on the binding to specific receptor subtypes. For example, static incubation of cultured human islets with sulpiride or haloperidol ( $500 \mathrm{nM})$, clozapine or olanzapine $(0.5$ and $5 \mu \mathrm{M}$, respectively) and $15 \mathrm{mM}$ glucose for $1 \mathrm{~h}$ increased glucose-stimulated insulin secretion (GSIS), with D2R antagonism as the proposed mechanism [85]. In a similar study, the effect of chlorpromazine, haloperidol, perphenazine, zuclopenthixol, clozapine, olanzapine and risperidone (all used at $1 \mu \mathrm{M}$ for $4 \mathrm{~h}$ ) on basal insulin secretion and GSIS was investigated in rat pancreatic islets. Whereas clozapine increased basal insulin release, haloperidol inhibited GSIS, and the other drugs had no significant effects. The study authors proposed that the stimulatory effect of clozapine on basal insulin release might explain its ability to increase appetite and induce weight gain [90]. Interestingly, the same group reported an increase in basal insulin release in rat pancreatic islets and INS-1 insulinoma cells with both olanzapine and clozapine $(1 \mu \mathrm{M}, 4 \mathrm{~h})$, and found a trend towards an increase in GSIS [91]. The same study reported an inhibition of GSIS with zuclopenthixol, a FGA. In line with these findings, a later study found that clozapine (1 or $10 \mu \mathrm{M})$ increased GSIS in isolated rat islets challenged with $10 \mathrm{mM}$ glucose (30 min) and, surprisingly, concomitantly suppressed the inhibitory action of glucose on glucagon release from pancreatic $\alpha$-cells [92]. Mechanistically, other authors found that the increase in basal insulin release in 
INS-1 cells at low glucose concentration in the presence of $25 \mu \mathrm{M}$ clozapine for $48 \mathrm{~h}$ upregulated the transcription factor Foxa1 and the mRNA levels of its downstream target the mitochondrial citrate carrier (Slc25A1 or CIC). Silencing of Foxa1 expression completely abolished basal insulin secretion in INS-1 cells treated with clozapine. By contrast, the FGA haloperidol ( $25 \mu \mathrm{M}$ for $24 \mathrm{~h})$ failed to modify Foxa1 levels and had no effect on insulin secretion [93]. The authors hypothesize that activation of Foxa1 by clozapine triggers exocytosis of insulin granules, but the molecular mechanism underlying such an effect remains to be elucidated. Overall, these in vitro studies suggest that the increase in basal insulin release and GSIS might explain the hyperinsulinemia associated with chronic treatment with SGAs in patients $[48,49,94]$.

Disruption of M3R action on glucose-dependent parasympathetic regulation of insulin secretion by SGAs has also been postulated. Johnson and collaborators [95] reported that olanzapine and clozapine, potent M3R antagonists, suppress cholinergic-stimulated insulin secretion by directly blocking these receptors in $\beta$-cells. In their study, carbachol $(10 \mu \mathrm{M})$, a cholinergic agonist, stimulated insulin secretion in rat islets perfused with $7 \mathrm{mM}$ (low) glucose during $30 \mathrm{~min}$, but co-treatment with 10-100 $\mathrm{nM}$ clozapine or olanzapine abolished carbachol-stimulated insulin secretion. Ziprasidone, risperidone and haloperidol, which lack affinity for M3R, did not change carbachol-stimulated insulin secretion. Of note, olanzapine, clozapine or ziprasidone alone, used at $10 \mu \mathrm{M}$, did not affect insulin secretion in rat islets in $8 \mathrm{mM}$ glucose compared with the vehicle condition, although the effect of high glucose concentration $(16.7 \mathrm{mM})$ was not reported in this study. These results were replicated by Sasaki and co-workers [96], who also reported inhibition of carbachol-stimulated insulin secretion in rat islets incubated with clozapine $(1-5 \mu \mathrm{M})$ and carbachol $(10 \mu \mathrm{M})$ in $7 \mathrm{mM}$ glucose medium for $1 \mathrm{~h}$. These researchers also explored the long-term effect of clozapine at high glucose concentration, reporting that clozapine $(1 \mu \mathrm{M})$ inhibited GSIS by $53 \%$ and reduced intracellular $\mathrm{Ca}^{2+}$ and ATP levels in rat islets, an effect observed after 7 days of culture. Likewise, clozapine $(1 \mu \mathrm{M})$ inhibited insulin secretion in rat islets stimulated by depolarization with $\mathrm{K}^{+}$and diazoxide $(250 \mu \mathrm{M})$ after incubation for 7 days, and also inhibited insulin secretion stimulated by protein kinase $C$ activation, but only when it was used at $5 \mu \mathrm{M}$ concentration. Therefore, it seems that clozapine suppresses ATP production in $\beta$-cells by reducing the closure of ATP-sensitive $\mathrm{K}^{+}$channels and decreasing the depolarization of the plasma membrane, which in turn leads to a decrease in $\mathrm{Ca}^{2+}$ influx, the driver of exocytosis of insulin granules. An acute inhibitory effect of clozapine $(5 \mu \mathrm{M})$ in isolated rat islets was reported by Best et al., following $60 \mathrm{~min}$ incubation [97]. Also, $\beta$-cell function was impaired by olanzapine and risperidone $(100 \mu \mathrm{M})$ in the hamster $\beta$-cell HIT-T15 line, with both drugs inducing endoplasmic reticulum stress activation via protein kinase R-like endoplasmic reticulum kinase (PERK) phosphorylation after 120 min of incubation [98]. In the case of olanzapine, however, the activation of the downstream mediator eukaryotic translation initiation factor $2 \alpha$ (eIF2 $\alpha$ ) was attenuated. Olanzapine, but not risperidone, blocked insulin secretion, and both proinsulin and insulin accumulated inside $\beta$-cells, explaining in part the accompanying cell death by apoptosis. Of relevance, treatment of isolated rat islets with $50 \mu \mathrm{M}$, but not $5 \mu \mathrm{M}$, chlorpromazine reduced the protein levels of IRS-2 and protein kinase C $\delta$ after $24 \mathrm{~h}$, without changes to IRS-1 [99]. This decrease was blocked by the $26 \mathrm{~S}$ proteasomal inhibitors MG-132 or lactacystin, suggesting that chlorpromazine induces IRS-2 degradation via the proteasomal pathway. Therefore, both SGA-induced endoplasmic reticulum stress and insulin signaling impairment in $\beta$-cells likely contribute to their dysfunction.

In spite of these data, controversy remains over the mechanism through which SGAs affect insulin secretion. Two scenarios could explain the diabetogenic properties of these drugs based on their effect on $\beta$-cells: (1) short-term stimulation of GSIS might lead to $\beta$-cell exhaustion in the long-term; (2) short-term inhibition of GSIS might lead to $\beta$-cell dysfunction in the long-term. Thus, a better understanding of the molecular mechanisms by which SGAs impact insulin secretion in $\beta$-cells and glucagon secretion in $\alpha$-cells is needed. 


\subsection{Animal Studies Addressing Disruption of Whole-Body Glucose Homeostasis by SGAs: Tissue-Specific Effects in Liver, Skeletal muscle and Pancreas}

The metabolic disturbances associated with SGA treatment can be accurately modeled in pre-clinical animal studies, which allow more sophisticated experimental procedures including the analysis of integral tissues and, therefore, provide valuable tools to understand the systemic effects of SGAs that could be translatable to the human population. Of relevance, many studies have used female rodents because of their better suitability for recapitulating AIWG and metabolic side-effects, although with the limitation of the assessment of glucose disturbances derived exclusively from the obesogenic effect of these drugs $[100,101]$. For this reason, most of the studies reviewed in this section report changes in glucose metabolism attributed to SGAs independently of body weight gain.

\subsubsection{SGAs Induce a Metabolic Shift to Fat Oxidation: Insulin-Resistance Condition}

In insulin-resistant states, there is a shift in the utilization of carbohydrate fuel to fat fuel, which also explains the typical elevation in plasma glucose levels. In this regard, the use of indirect calorimetry to measure the respiratory exchange ratio (RER), which is used to assess the type of fuel being utilized by the body, has revealed that animals treated with SGAs show a shift from carbohydrate to fat oxidation. For example, acute oral treatment of male C57BL/6 mice with a single dose of olanzapine (2.5 and $5 \mathrm{mg} / \mathrm{kg}$ ), clozapine ( 5 and $10 \mathrm{mg} / \mathrm{kg}$ ) or risperidone $(2.5$ and $5 \mathrm{mg} / \mathrm{kg}$ ) induced a dose-dependent lowering of the RER (indicting fat oxidation) within minutes, whereas aripiprazole $(1,5$ and $10 \mathrm{mg} / \mathrm{kg}$ ) had only a modest effect [102]. In the same study, clozapine, risperidone and olanzapine also influenced whole-body cellular respiration by decreasing the rate of oxygen consumption (VO2), but only at the highest doses. The authors reported no changes in RER and VO2 when mice were treated orally with the H1R antagonists astemizole $(3 \mathrm{mg} / \mathrm{kg}$ ) and terfenadine $(10 \mathrm{mg} / \mathrm{kg})$, suggesting that $\mathrm{H} 1 \mathrm{R}$ is not involved in these responses. Other researchers have shown the same lowering effects of olanzapine for RER and $\mathrm{VO} 2$ in male and female wild-type and glucagon receptor-knockout mice treated with a single dose (5 mg/kg, intraperitoneal, i.p.) over $120 \mathrm{~min}$ [103], and also in female Sprague-Dawley rats $(10 \mathrm{mg} / \mathrm{kg}$, orally) during a $24 \mathrm{~h}$ period [104].

\subsubsection{The Role of the Liver in Mediating SGAs-Induced Disturbances in Glucose Metabolism}

SGA-associated impairment in glucose production, leading to hyperglycemia and hepatic insulin resistance, has been extensively studied in animal models and can be attributed not only to a primary effect in the liver, but also to secondary effects mediated by the CNS. The bulk of studies utilize HEC analysis to assess insulin sensitivity via continuous infusion of insulin. The incorporation of radioactive-labeled glucose can also be used to measure glucose uptake in individual organs. Overall, many studies highlight the liver as a main target for olanzapine and clozapine, the most diabetogenic of the SGAs. In an acute study in male Wistar rats by Houseknecht and collaborators [105] using the HEC technique with continuous infusion of insulin $(3 \mathrm{mU} / \mathrm{kg} / \mathrm{min})$, subcutaneous (s.c.) administration of clozapine $(10 \mathrm{mg} / \mathrm{kg})$ or olanzapine $(3.2 \mathrm{and} 10 \mathrm{mg} / \mathrm{kg})$ substantially reduced the glucose infusion rate (GIR), an indicator of insulin resistance, and at the same time increased hepatic glucose output (HGO), a measure of both gluconeogenesis and glycogenolysis, but only in those animals receiving the higher dose. Administration of ziprasidone $(3.2-30 \mathrm{mg} / \mathrm{kg})$ or risperidone $(2 \mathrm{mg} / \mathrm{kg}) \mathrm{had}$ no effect on these parameters. In line with these results, an increase in HGO and a decrease in GIR was reported in male Sprague-Dawley rats administered olanzapine ( $3 \mathrm{mg} / \mathrm{kg}$, s.c.) measured by HEC with continuous insulin infusion (5 $\mathrm{mU} / \mathrm{kg} / \mathrm{min}$ ) [106], and this was also reported in a similar study in male Sprague-Dawley rats treated with clozapine $(10 \mathrm{mg} / \mathrm{kg}$, s.c.) or olanzapine (3 mg/kg, s.c.) [107]. The latter study did not find any impairment in insulin sensitivity with a single-dose of ziprasidone ( $3 \mathrm{mg} / \mathrm{kg}$, s.c.) or haloperidol ( $0.25 \mathrm{mg} / \mathrm{kg}$, s.c.). Martins and co-workers [108] compared peripheral and central routes of olanzapine administration in male Sprague-Dawley rats, and found that intravenous (i.v.) olanzapine injection $(4.5 \mathrm{mg} / \mathrm{kg}$ ) or intracerebroventricular (i.c.v.) administration (330 $\mu \mathrm{g})$ reduced GIR and increased HGO. In a similar study, adult male Wistar rats treated with intragastric olanzapine 
infusion $(30 \mathrm{mg} / \mathrm{kg} / \mathrm{h}$ ) and subjected to either "low" (continuous infusion of insulin at $3 \mathrm{mU} / \mathrm{kg} / \mathrm{min}$ ) or "high" (9 mU/kg/min) HEC analysis showed reduced GIR and hepatic glycogen content, with an increase in HGO detected in the high insulin-infusion group [109]. Another single-dose study described that hepatic glycogen content in fasted female Sprague-Dawley rats was reduced in the first hour after oral administration of clozapine $(12 \mathrm{mg} / \mathrm{kg})$, and the rats also developed hyperglycemia [110]. In the setting of repeated dose-experiments, a study in female Sprague-Dawley rats chronically treated with olanzapine ( 2.0 or $7.5 \mathrm{mg} / \mathrm{kg}$ ) via osmotic mini-pumps for 4 weeks followed by HEC analysis (insulin infusion at $5 \mathrm{mU} / \mathrm{kg} / \mathrm{h}$ ) revealed reduced GIR and increased HGO in both treatment groups compared with control rats [111]. Overall, irrespective of the different administration routes, doses used and periods of treatment, all of these studies in rat point to an elevation in HGO together with a reduction in GIR-hallmarks of insulin resistance-as well as a reduction of hepatic glycogen content independently of changes in body weight; thus, confirming a direct effect of SGAs on hepatic glucose metabolism.

SGA treatments have been also associated with alterations in the gluconeogenesis pathway in several studies. For instance, upregulation of glucose-6-phosphatase (G6pc) mRNA was reported in single-dose experiments of olanzapine ( $15 \mathrm{nmol}$, i.c.v.) in male ICR mice [112], in male Sprague-Dawley rats receiving an infusion of olanzapine (prime $22 \mu \mathrm{g} / \mathrm{min}$ for $5 \mathrm{~min}$, then $1.9 \mu \mathrm{g} / \mathrm{min}$ for $60 \mathrm{~min}$, i.c.v.) [108], and in male Wistar rats after an oral chronic treatment with clozapine $(10 \mathrm{mg} / \mathrm{kg})$ during 6 weeks [113]. Likewise, an increase in phosphoenolpyruvate carboxykinase (PEPCK) protein levels was reported in the liver of pancreatectomized male Sprague-Dawley rats treated orally with chlorpromazine $(50 \mathrm{mg} / \mathrm{kg} / \mathrm{d})$ for 8 weeks [114] and also increased mRNA levels were found in the liver of female Sprague-Dawley rats treated for 14 days with clozapine $(7.5 \mathrm{mg} / \mathrm{kg} / \mathrm{d}$, s.c., twice daily), which was accompanied by augmented mRNA levels of hepatic Hsd11b1 (encoding $11 \beta$-hydroxysteroid dehydrogenase type 1), a key regulatory enzyme of glucocorticoid metabolism linked to T2D [75]. Regarding SGA-induced hepatic metabolic dysfunction, chronic treatment of female C57Bl/6 mice with olanzapine $(8 \mathrm{mg} / \mathrm{kg} / \mathrm{d})$ via osmotic mini-pumps for 28 days induced anaerobic glycolysis and caused a pseudo-fasted state that depleted hepatic glycogen reserves and activated AMPK signaling. This treatment also increased the hepatic concentration of glutamate and its metabolites, resulting in the activation of mammalian target of rapamycin (mTORC1) signaling in the liver. These data suggest that disturbances in glucose metabolism in the liver caused by olanzapine may be mediated, at least in part, by the simultaneous activation of both catabolic (AMPK) and anabolic (mTORC1) pathways [115]. Importantly, under conditions in which HGO is stimulated by pyruvate administration, a dose-time-dependent hyperglycemic effect of quetiapine was observed in wild-type mice but not in mice with a liver-specific depletion of the circadian clock-component Bmal1, pointing to a derangement in the circadian rhythmicity of HGO [116]. Because HGO peaks in the early morning in humans, this study suggests that a daily evening dose of quetiapine might be safer than a morning dose.

Accumulating evidence strongly associates an impairment of hepatic insulin signaling in animals treated with SGAs. Generally, these drugs provoke a decrease in the phosphorylation of AKT, a critical node of insulin signaling in the liver. For example, oral administration of olanzapine $(3 \mathrm{mg} / \mathrm{kg} / \mathrm{d}$, twice daily) or clozapine ( $20 \mathrm{mg} / \mathrm{kg} / \mathrm{d}$, twice daily) in female Sprague-Dawley rats for 9 weeks led to glucose intolerance and reduced hepatic levels of AKT phosphorylation at Ser ${ }^{473}$ and GSK3 $\beta$ phosphorylation at $\mathrm{Ser}^{9}$ levels, in parallel with an up-regulation of H1R and M3R levels [117]. As outlined in the previous sections, most of the diabetogenic properties of SGAs are attributed to their H1R and M3R antagonism. M3R antagonism is related to the inhibition of insulin secretion, but it does not seem to have a role in hepatic glucose homeostasis, as demonstrated in studies in mice lacking M3R in hepatocytes [118]. This latter finding points to the up-regulation of H1R as responsible for the impairment in insulin signaling, with H1R engagement of SGAs inducing weight gain and dysregulation of glucose metabolism by impairing AMPK signaling.

Regarding SGAs-mediated impairment of insulin signaling in the liver, Townsend and collaborators [119] reported that AKT Ser ${ }^{473}$ phosphorylation was completely inhibited in obese male C57BL/6 mice pre-treated for one hour with olanzapine (5 mg/kg i.p.) before an insulin injection, as compared with lean C57BL/6 mice 
receiving the same treatment. By contrast, Smith and co-workers [78] showed that the effects of daily dosing with clozapine $\left(10 \mathrm{mg} / \mathrm{kg}\right.$, s.c.) during 7 or 28 days did not decrease AKT Ser ${ }^{473}$ phosphorylation. These authors demonstrated that the derangements in glucose metabolism induced by clozapine were mediated by an increase in glucagon secretion, leading to elevated HGO. In a subsequent study, they demonstrated that clozapine simultaneously stimulates insulin and glucagon secretion, a condition that might explain the concurrence of high glucose and high insulin levels in treated animals [92]. Reinforcing these findings, glucagon receptor-knockout male and female C57BL/6J mice were protected against olanzapine $(5 \mathrm{mg} / \mathrm{kg}$, i.p.)-induced hyperglycemia in an acute study $(120 \mathrm{~min})$, in association with reduced protein content of PEPCK and glucose-6-phosphatase (G6Pase) in the liver [103]. In another study, male Sprague-Dawley rats treated for 8 weeks with olanzapine $\left(5 \mathrm{mg} / \mathrm{kg} / \mathrm{d}\right.$, gavage) showed an increase in IRS-1 Ser ${ }^{307}$ and IRS-2 Ser ${ }^{731}$ phosphorylation, which is reported to trigger their proteosomal degradation, resulting in the blockade of insulin signaling [120]. In line with these findings, pancreatectomized male Sprague-Dawley rats treated orally with chlorpromazine $(5.50 \mathrm{mg} / \mathrm{kg} / \mathrm{d}$ ) for 8 weeks showed diminished hepatic IRS-2 protein levels and reduced AKT Ser ${ }^{473}$ phosphorylation, together with decreased GIR and increased HGO during HEC analysis [114], all features of hepatic insulin resistance. Interestingly, the authors showed that the metabolic side-effects of chlorpromazine could be mitigated by combining the treatment with exercise. Confirming the impairment of the critical nodes of insulin signaling in the liver by SGAs, an analysis of male Sprague-Dawley rats administered with haloperidol $(2 \mathrm{mg} / \mathrm{kg} / \mathrm{d})$ or olanzapine $(10 \mathrm{mg} / \mathrm{kg} / \mathrm{d})$ during 8 weeks via osmotic mini-pumps revealed that only olanzapine decreased hepatic IRS-2 and GSK3 $\alpha \operatorname{Ser}^{21}$ phosphorylation, and also increased phospho-GSK3 $\beta \operatorname{Ser}^{9}$ levels, with haloperidol having no effect [121]. Moreover, the expression of TCF7L2, a key effector of the Wnt signaling pathway strongly associated with glucose homeostasis, was increased in the livers of male C57BL/6 mice treated orally with olanzapine ( $4 \mathrm{mg} / \mathrm{kg} / \mathrm{d})$ for 8 weeks [122]. Reinforcing the local action of SGAs in the liver, antidiabetic drugs that prevent hepatic insulin resistance, such as metformin and rosiglitazone, were found to counteract the metabolic adverse effects of SGAs in a tissue-specific manner [122-124].

As alluded to earlier, SGAs can have secondary effects mediated by the CNS and the descending sympathetic and parasympathetic systems, which innervate the liver, skeletal muscle, pancreas, and adipose tissue, and also disrupt glucose homeostasis in these organs. By using central administration routes, several studies have indicated that hepatic insulin resistance can be due to a direct action of these drugs in the orexigenic neurons of the hypothalamus via induction of AMPK, and the subsequent stimulation of hepatic gluconeogenesis through the sympathetic nervous system [108,112]. In this regard, it was previously demonstrated in female Sprague-Dawley rats that oral administration of olanzapine $(1 \mathrm{mg} / \mathrm{kg}$, 3 times daily for 8,16 and 36 days) activates hypothalamic AMPK via blockade of H1R and that this effect is attenuated by the H1R agonist 2-(3-trifluoromethylphenyl) histamine [125]. By contrast, another study [126] found that subchronic oral exposure of female Sprague-Dawley rats to olanzapine $(6 \mathrm{mg} / \mathrm{kg} / \mathrm{day})$ for 6 days led to the up-regulation of neuropeptide $\mathrm{Y}$ and agouti-related protein and the down-regulation of proopiomelanocortin in the arcuate nucleus of the hypothalamus, both in rats fed ad libitum and pair-fed. Interestingly, despite weight gain and increased expression of orexigenic neuropeptides, AMPK phosphorylation levels were reduced, an effect not observed after acute administration of either olanzapine or clozapine. Overall, these data suggest that olanzapine-induced hyperphagia is mediated through specific changes in hypothalamic neuropeptides without the requirement of concomitant AMPK activation.

Disruption of M3R density in the brain has also been observed in female SD rats treated with olanzapine (0.25-2.0 mg/kg, self-administered orally in a sweet cookie pellet, 3 times/day for 14 days), which resulted in an up-regulation of M3R in the hypothalamic arcuate ventromedial nuclei and dorsal vagal complex of the brainstem, CNS regions that regulate systemic glucose homeostasis [88]. Elevated hypothalamic M3R levels correlated negatively with peripheral insulin, and positively with ghrelin, cholecystoquinin, food intake and body weight, suggesting that increased M3R density in the CNS is a compensatory mechanism in response to M3R antagonism by olanzapine, which could also disrupt peripheral glucose homeostasis. The promotion of increased HGO secondary to an initial effect in the 
hypothalamus has also been reported by Girault and co-workers [127], who found that infusion of olanzapine $(3 \mathrm{mg} / \mathrm{kg})$ in male RccHan;Han rats activated orexin A-positive neurons in the hypothalamus, which triggered HGO via sympathetic innervation in the liver. Likewise, olanzapine $(10 \mu \mathrm{M})$ treatment of both male and female C57BL/6J mice reduced the excitability of isolated neurons of the dorsal motor nucleus of the vagus nerve [128], whose activation has been linked to reductions in HGO [129]. Thus, it can be hypothesized that olanzapine-mediated decrease in the vagus nerve neuronal activity would lead to increased HGO. On the other hand, modulation of the endocannabinoid system has been suggested as a good strategy to overcome SGA-induced metabolic side-effects. In a 15-day study in female Wistar rats, olanzapine $(4 \mathrm{mg} / \mathrm{kg} / \mathrm{d}$, administered by oral gavage twice daily)-activated hypothalamic orexin was attenuated by co-treatment with the cannabinoid receptor type 1 antagonist NESSO6SM, $(10 \mathrm{mg} / \mathrm{kg}$, administered by oral gavage daily), which also restored pyruvate kinase levels in the liver, strengthening the role of the CNS in modulating peripheral SGAs effects [130].

In contrast to the aforementioned results, some acute SGA studies failed to find CNS-mediated effects on hepatic glucose metabolism. For example, Hahn and co-workers [131] found that a single-dose of olanzapine (75 $\mu$ g, i.c.v.) in male Sprague-Dawley rats had no effect on HGO and GIR. Furthermore, in the study of Girault and co-workers [109] intragastric administration of olanzapine (3 mg/kg/h) in male Wistar rats led to hyperglycemia and increased corticosterone levels whereas i.c.v. infusion $(30 \mu \mathrm{g} / \mathrm{kg} / \mathrm{h})$ failed to change glycemia compared with control rats. However, the lack of effect of olanzapine in this study could be due to the low doses in comparison with, for example, the acute study of Martins and co-workers [108] who reported a central (via i.c.v.) effect of olanzapine with a $330 \mu \mathrm{g}$ dose. Moreover, a study by Kowalchuk et al. [132] showed that a single-dose of olanzapine ( $2 \mathrm{mg} / \mathrm{kg}$, s.c.) in male Sprague-Dawley rats during a pancreatic euglycemic clamp, a technique that allows manipulation of central insulin concentrations via i.c.v. infusion of insulin and the concomitant blockade of peripheral insulin action by somatostatin infusion, increased HGO possibly by impairing the ability of central insulin to suppress it. The summarized effects of SGAs on hepatic insulin signaling and glucose metabolism are shown in Figure 2.

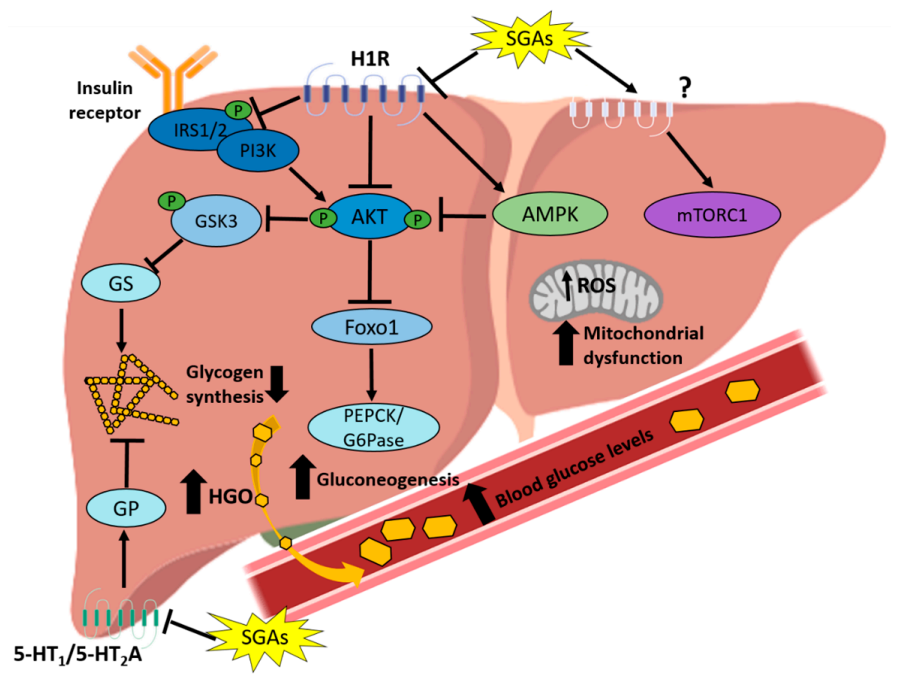

Figure 2. SGA-induced impairment in hepatic insulin signaling and glucose metabolism. SGAs impact the insulin signaling pathway at two levels: inhibition of IRS-1/2 phosphorylation and inhibition of AKT and GSK3 phosphorylation, with H1R antagonism being the proposed SGA target in insulin signaling impairment. Antagonism of $5-\mathrm{HT}_{1}$ and $5-\mathrm{HT}_{2} \mathrm{~A}$ and inhibition of glycogen phosphorylase (GP) would decrease glycogen synthesis, an effect also enhanced by inhibition of glycogen synthase (GS). Both inhibition of glycogen synthesis and stimulation of gluconeogenesis by SGAs increase the hepatic glucose output (HGO), leading to an increase in blood glucose levels. SGAs have been also shown to activate both hepatic catabolic (AMPK) and anabolic (mTORC1) pathways and also induce ROS production and mitochondrial dysfunction. 
2.2.3. Effects of SGAs on Insulin Sensitivity and Glucose Transport in the Skeletal Muscle of Animal Models

As the main tissue involved in insulin-stimulated glucose uptake, insulin resistance and hyperglycemia associated with SGA medication may be generated in the skeletal muscle $[109,111]$. In agreement with the earlier in vitro studies, a single dose of quetiapine $(10 \mathrm{mg} / \mathrm{kg}$, i.p. $)$ downregulated the expression of phosphatidylinositol 3-kinase, regulatory subunit, polypeptide 1 (Pik3r1), a critical regulator of the insulin signaling pathway, in the skeletal muscle of male ICR mice fed a chow diet. This effect was reversed in mice fed a dietary cholecalciferol supplement, again suggesting the importance of vitamin D supplementation in SGA-induced metabolic side-effects [77]. Moreover, the beneficial impact of exercise has been tested in female Sprague-Dawley rats treated with olanzapine $(10 \mathrm{mg} / \mathrm{kg}$, s.c.) for 9 weeks, with an increase in GLUT4 levels reported in gastrocnemius muscle samples compared with the levels in sedentary rats [133]. While there is no available data on the effects of SGAs on GLUT4 transporter in skeletal muscle, it could be speculated that AMPK activation/expression via H1R blockade could have a direct effect on this tissue by inhibiting translocation, although AMPK activation has been extensively linked to increased glucose uptake in skeletal muscle [134]. A study in male Sprague-Dawley rats examining the effect of olanzapine infusion $(1 \mathrm{mg} / 100 \mathrm{~g}$ of body weight for $0.5 \mathrm{~h}$ and then $0.04 \mathrm{mg} / 100 \mathrm{~g} / \mathrm{h}$ continuously for $23.5 \mathrm{~h}$ ) on muscle fibers reported an increase in the expression of genes involved in glycolysis, with the exception of the skeletal muscle form of hexokinase (Hk2), and some genes of lactate metabolism such as lactate dehydrogenase A $(L d h A)$ and the lactate transporter moxocarboxylate transporter 1 (Mct1). Olanzapine treatment also resulted in a down-regulation of most of the genes involved in the citric acid cycle, indicating that this drug seems to promote a switch from an oxidative to a more glycolytic fiber type [135].

In contrast to in vivo data, ex vivo analysis of glucose uptake in isolated epitrochlearis skeletal muscle from male Wistar rats treated with olanzapine $(10 \mathrm{mg} / \mathrm{kg}$, s.c.) or clozapine $(10 \mathrm{mg} / \mathrm{kg}$, s.c) for 5 days failed to find changes in insulin-stimulated glucose uptake [105]. Similar to the findings in liver, TCF7L2 protein levels were increased in skeletal muscle in male C57BL/6 mice treated with intragastric olanzapine $(4 \mathrm{mg} / \mathrm{kg} / \mathrm{d})$ for 8 weeks, an effect ameliorated by co-treatment with metformin $(150 \mathrm{mg} / \mathrm{kg} / \mathrm{d})$ [122]. The summarized effects of SGAs on skeletal muscle insulin signaling and glucose metabolism are shown in Figure 3.

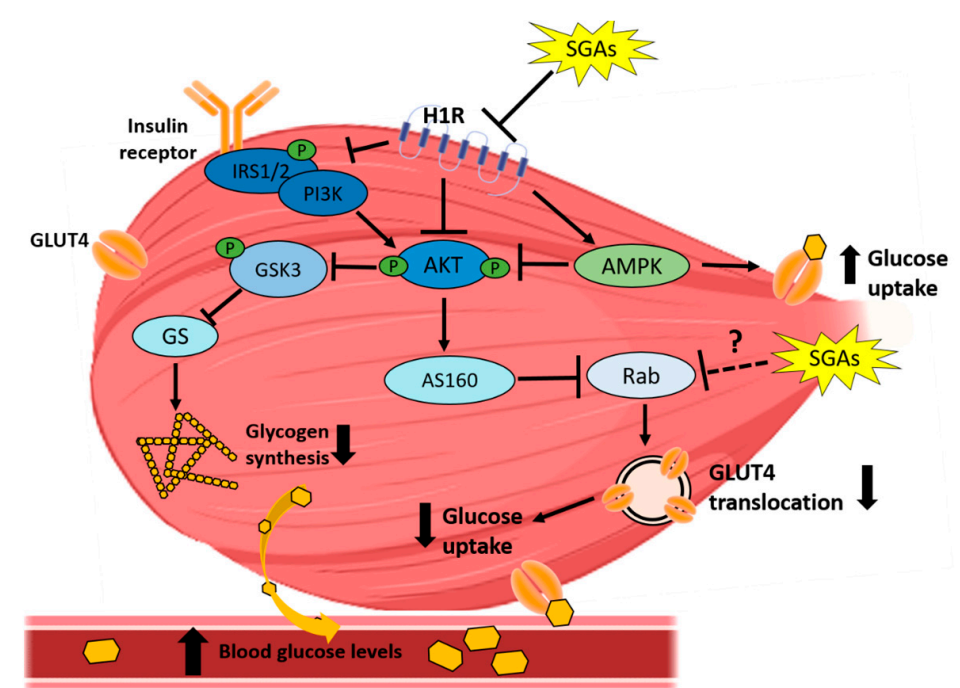

Figure 3. SGA-induced impairment in skeletal muscle insulin signaling and glucose uptake. SGAs impact the insulin signaling pathway at two levels: inhibition of IRS-1/2 phosphorylation and inhibition of AKT and GSK3 phosphorylation, with H1R antagonism being the proposed SGAs target in insulin signaling impairment. SGAs could also increase glucose uptake via AMPK activation, although these drugs most likely exert inhibition of this effect. GLUT4 translocation has been proposed a plausible target for SGAs-reduced glucose uptake in muscle. 


\subsubsection{Effects of SGAs on the Endocrine Pancreas: Impairment of Insulin and Glucagon Secretion}

As shown by the results in vitro and ex vivo, SGAs directly impact pancreatic islets to regulate insulin and glucagon secretion. Indeed, HEC, which provides an index of the secretory capacity of $\beta$-cells, has revealed a direct effect of these drugs on insulin secretion. For instance, in an HEC study in male Sprague-Dawley rats, a single dose of olanzapine ( $3 \mathrm{mg} / \mathrm{kg}$, s.c.) decreased insulin secretion and C-peptide levels in response to glucose [106]. Similarly, an HEC study assessing the effects of different antipsychotics showed that acute administration of olanzapine $(3 \mathrm{mg} / \mathrm{kg}$, s.c.) or clozapine (10 mg/kg, s.c.) to male Sprague-Dawley rats decreased GSIS, whereas risperidone (1 mg/kg, s.c.), haloperidol ( $0.25 \mathrm{mg} / \mathrm{kg}$, s.c.) and ziprasidone (3 $\mathrm{mg} / \mathrm{kg}$, s.c.) had no effect. These findings suggest that the common SGAs olanzapine and clozapine can hinder $\beta$-cell compensation through a direct effect on insulin secretion [107]. In repeated-dose studies, female Sprague-Dawley rats treated orally with self-administrated olanzapine $(0.25-2 \mathrm{mg} / \mathrm{kg}, 3$ times per day for 14 days) showed reduced fasting insulin levels [136]. Likewise, in a previously-mentioned study, pancreatectomized male Sprague-Dawley rats treated orally with chlorpromazine $(50 \mathrm{mg} / \mathrm{kg} / \mathrm{d})$ for 8 weeks showed a decrease in the first and second phase of insulin secretion during a hyperglycemic clamp. Interestingly, the islets from these animals showed reduced glucokinase protein levels at the end of the treatment without changes in GLUT2 expression, and this was accompanied by impairment of the insulin signaling pathway as evidenced by a decrease in protein levels of IRS-2, Pdx1 and phosphorylated AKT Ser ${ }^{473}$, similar to the in vitro findings in isolated islets [99]. The same researchers reported these molecular alterations in pancreatectomized and ovariectomized female Sprague-Dawley rats treated orally with olanzapine $(2 \mathrm{mg} / \mathrm{kg} / \mathrm{d})$ for 8 weeks, also showing decreased $\beta$-cell mass. By contrast, risperidone $(0.5 \mathrm{mg} / \mathrm{kg} / \mathrm{d})$ treatment did not produce significant effects. Interestingly, co-treatment with estrogens reversed the negative impact of olanzapine, suggesting that it should be avoided in the treatment of postmenstrual females [137]. Overall, it could be thought that inhibition of insulin secretion by SGAs is due to blockade of M3R, as previously described in vitro, in addition to impairment of insulin signaling in $\beta$-cells. However, in other repeated-dose studies, female Sprague-Dawley rats chronically treated with olanzapine $(2.0$ or $7.5 \mathrm{mg} / \mathrm{kg}$ ) with osmotic mini-pumps for 4 weeks showed no changes related to insulin secretion or C-peptide levels compared with animals receiving vehicle [111]. Conversely, continuous infusion of olanzapine ( 4 or $8 \mathrm{mg} / \mathrm{kg} / \mathrm{d}$ ) for 30 days with mini-pumps in female CD-1 mice led to hyperglycemia in an oral glucose tolerance test and increased serum insulin only at the highest dose used. Interestingly, pancreatic insulin content was elevated in mice treated at the higher dose of olanzapine [138]. Thus, SGAs impair insulin secretion and the insulin-signaling pathway, although the associated molecular mechanisms remain uncertain. Of relevance, the acute inhibitory effect of GSIS by clozapine and olanzapine points to an inhibition of M3R signaling. As we previously mentioned, activation of M3R leads to increased insulin secretion, whereas M3R blockade induces its inhibition [95,139]. The effects are, however, less clear for 5-HT receptors. For example, treatment of male Sprague-Dawley rats with a single dose of MDL100907 (0.5 mg/kg, s.c.), a 5-HT 2 A antagonist, decreases both insulin and C-peptide secretion [140]. Importantly, in human and mouse islets activation of $5-\mathrm{HT}_{2} \mathrm{~B}$ increase GSIS [87]. However, ex vivo studies reported that treatment of islets from $d b / d b$ mice with the 5- $\mathrm{HT}_{2} \mathrm{C}$ antagonist SB242084 (1-10 $\left.\mu \mathrm{M}\right)$ increases insulin secretion, whereas the 5- $\mathrm{HT}_{2} \mathrm{C}$ agonist m-chlorophenylpiperazine (mCPP) $(5-100 \mu \mathrm{M})$ inhibits insulin secretion in control islets [141]. In diet-induced insulin resistant states or pregnancy, $5-\mathrm{HT}_{3} \mathrm{~A}$ is necessary for $\beta$-cell compensation by increasing insulin secretion [142,143]. Thus, the complex influence of 5-HT signaling, and the different 5-HT receptors targeted by SGAs raises the complexity of the effect of these drugs on insulin secretion. Finally, the increase in insulin secretion mediated by D2R antagonism may predispose to the depletion of insulin granules and $\beta$-cell exhaustion in the long term [144]. Of interest, bromocriptine, a D2R agonist, was approved in 2009 as an antidiabetic, suggesting the opposite effect to diabetogenic D2R antagonists [145]. Another study from Hahn and co-workers [131] has suggested that SGAs could impair insulin secretion via centrally mediated mechanisms by addressing the effect of an i.c.v. injection 
of olanzapine $(75 \mu \mathrm{g})$ in male Sprague-Dawley rats during a hyperglycemic clamp, reporting decreased insulin and C-peptide secretion.

Beyond the direct and/or indirect effects of APDs in $\beta$-cells, several studies report that they increase the levels of glucagon in $\alpha$-cells [78,92]. Indeed, chronic treatment of male Sprague-Dawley rats with clozapine $(10 \mathrm{mg} / \mathrm{kg}$, s.c.) or quetiapine $(10 \mathrm{mg} / \mathrm{kg}$, s.c.) for 42 days increased insulin and glucagon levels and decreased GLP-1, an inhibitor of glucagon secretion, in obese and lean rats [146]. This increase in glucagon levels can directly increase HGO, as mentioned previously. In this line, it was reported that the GLP-1 receptor agonist exenatide reversed the damage to pancreatic islets in male C57BL $/ 6$ mice treated for 4 months with clozapine $(13.5 \mathrm{mg} / \mathrm{kg}$, orally), suggesting a dysregulation of GLP-1-mediated signaling and the subsequent impairment of pancreatic hormone secretion [147]. An increase in glucagon levels after clozapine treatment $(5 \mathrm{mg} / \mathrm{kg}$, i.v.) has also been observed in male Wistar rats [148]. The mechanism by which SGAs can stimulate glucagon secretion is, however, not known, but it is unlikely to be due to M3R antagonism, as agonism of these receptors stimulates both insulin and glucagon secretion, as demonstrated in mice with genetic deletion of this receptor [139]. The increase in glucagon secretion and subsequent stimulation of HGO can also stimulate insulin secretion, which could explain the hyperinsulinemia found in patients despite the inhibitory effect of SGAs on GSIS in the initial stages of the treatment. It is worth mentioning that the hyperinsulinemia associated with these drugs can directly impact on AKT/GSK3 signaling in other tissues. For instance, activation of the AKT/GSK3 pathway in the brain of fasted male Sprague-Dawley rats after clozapine treatment $(10 \mathrm{mg} / \mathrm{kg}$ ) was reported to be due to an increase in the levels of insulin (which can cross the blood-brain barrier) and not to a direct effect of the drug [149]. Thus, although current evidence points to SGA-induced glucagon release, the effects on $\alpha$-cells are not known and more research is needed. The summarized effects of SGAs on beta-cells insulin secretion and alpha-cells glucagon secretion are shown in Figure 4.

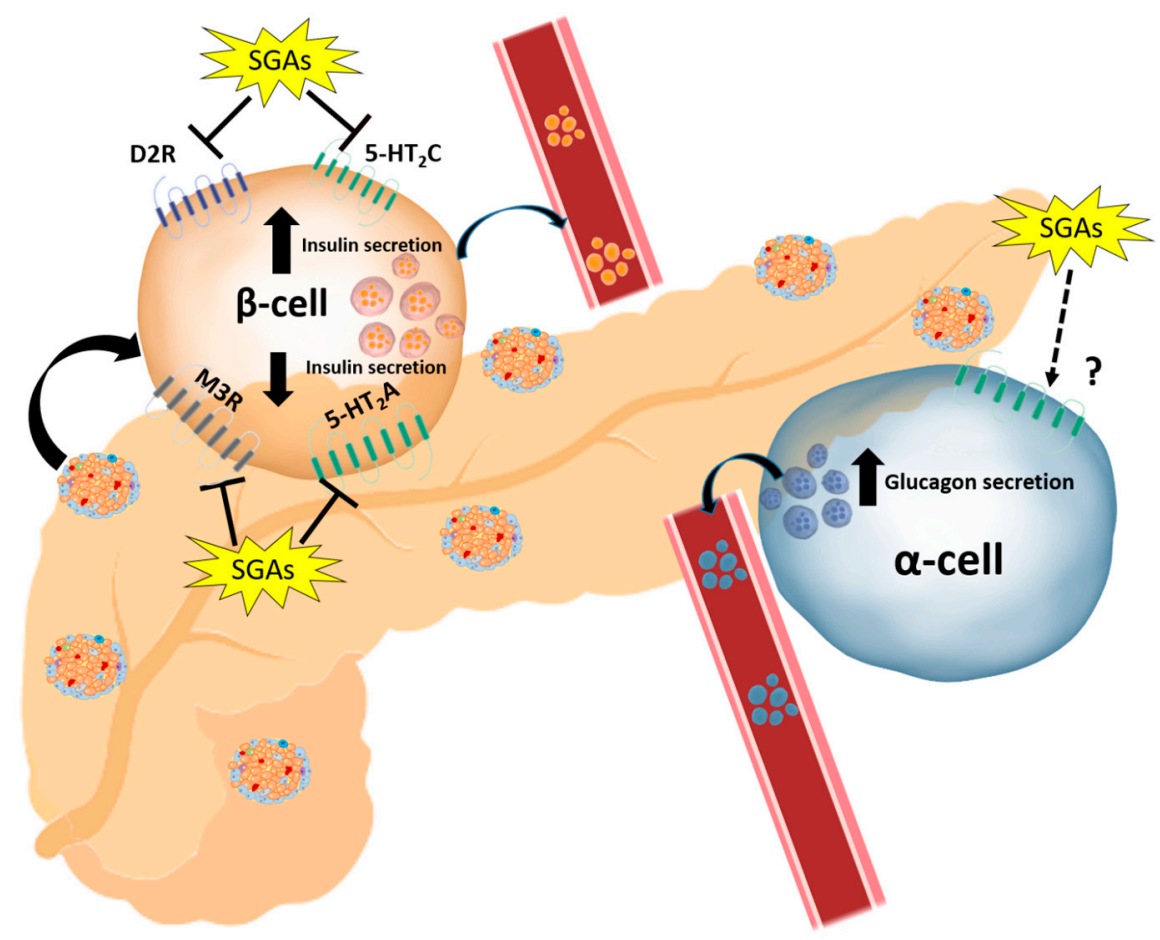

Figure 4. SGA-induced impairment in insulin secretion from $\beta$-cells and glucagon secretion from $\alpha$-cells. The complexity of SGAs impact on insulin secretion is based on the effect mediated by antagonism of SGAs at different receptors. Antagonism of D2R and 5- $\mathrm{HT}_{2} \mathrm{C}$ stimulates insulin secretion, while antagonism of M3R and 5- $\mathrm{HT}_{2} \mathrm{~A}$ inhibits this effect. The receptors implicated in the stimulation of glucagon secretion are still unknown. 


\subsection{Completing the Preclinical Model Picture: Genetic and Epigenetic Determinants of SGAs-Induced Metabolic Side-Effects in Humans}

Studies in animal models have been instrumental in identifying the molecular mechanisms underlying the metabolic side-effects of SGAs with techniques that cannot be applied to humans. Nevertheless, minimally invasive procedures in schizophrenia and SGA-treated patients have helped to unravel the potential genetic component of the variability of metabolic side-effects among patients. To date, most of the studies investigating the potential genetic drivers of SGA-induced metabolic side-effects have used highly accessible tissues such as blood leukocytes or peripheral blood mononuclear cells, although some studies have used extracted DNA from tissue biopsies. There are many excellent reviews addressing the genetic and epigenetic markers of both schizophrenia per se and the differential response to SGAs [150] as well as AIWG [151,152], and so here we will only illustrate the genetic traits of the main molecular effectors in SGA-induced dysregulation of glucose homeostasis.

Several genes expressed in skeletal muscle have emerged as potential candidates for SGA-induced metabolic dysfunction. Given the strong influence of these medications on $A K T$ expression levels, gene-specific methylation patterns in the promoters of $A K T 1,2$ and 3 were analyzed in fasting skeletal muscle biopsies from 16 patients with bipolar disorders treated with an SGA (quetiapine, risperidone, olanzapine, asenapine or aripiprazole) and compared with 14 patients treated with mood stabilizers for at least 3 months. Methylation of $A K T 1$ and $A K T 2$ was higher in SGA-treated patients than in patients treated with mood stabilizers, whereas no differences were found in AKT3 methylation [153]. Accordingly, increased $A K T$ promoter methylation might explain the decreased insulin sensitivity in skeletal muscle associated with treatment, as increased methylation in the gene promoters is generally linked to decreased gene expression and functionality. In a similar study, Emamian et al. [154] screened various protein kinases and phosphatases in 28 individuals with schizophrenia and 28 controls, finding significant differences only for AKT1 protein levels. They also compared post-mortem brains of patients with schizophrenia and control individuals, and also found a decrease in AKT1 protein and phosphorylated GSK3 $\beta$ in the hippocampus and frontal cortex of individuals with schizophrenia, pointing to AKT1 as a possible susceptibility marker for schizophrenia. Other mediators of the insulin-signaling pathway have not been associated with SGA-induced metabolic side-effects. In a cross-sectional study of 438 patients, Moons and colleagues failed to identify an association between DNA methylation of IGF1 and IGF2 promoters and SGA-induced metabolic side-effects [155]. In a study searching for candidate genes in skeletal muscle from 195 patients with schizophrenia medicated with SGAs, a moderate association was found between the polymorphism rs 9852 variant in $T B C 1$ domain family member 1 protein (TBC1D1), a Rab-GTPase that regulates GLUT4 trafficking, and lowers weight gain, although the functional relevance is unknown [156]. Interestingly, a previous study demonstrated that TBC1D1 is a substrate of AKT and AMPK and that Tbc1d1-deficient mice have impaired insulin-stimulated glucose transport and reduction of GLUT4 abundance in skeletal muscle [157]. Thus, gene polymorphisms in TBC1D1 could explain disturbances in glucose metabolism with SGAs and different responses between patients.

Other potential candidate genes have been discovered by focusing on gene variants that can affect $\beta$ and $\alpha$-cell functionality. For example, the rs10423928 polymorphism (A/T) in the $\beta$-cell glucose-dependent insulinotropic polypeptide receptor (GIPR), which stimulates insulin secretion upon binding of the incretin GIP, was associated with increased insulin levels in an oral glucose tolerance test in patients with schizophrenia treated with olanzapine [158]. As discussed earlier, long-term treatment with high-risk diabetogenic SGAs has been also linked to decreased GLP-1 levels in rats [146], and the positive effects of GLP-1 analogs have been proved in animals [147] and humans [159,160]. Correspondingly, GCG (encoding for a preprotein cleaved into four different proteins, including GLP-1 and glucagon) and GLP1R have been assessed as potential pharmacogenetic markers of antipsychotic response. In an analysis of 216 patients with schizophrenia treated with clozapine or olanzapine, Brandl and collaborators [161] found an association between rs13429709, a single-nucleotide polymorphism located near GCG, and weight gain. In a similar analysis, the Clinical Trial of Antipsychotic Intervention Effectiveness (CATIE) study 
examined whether genetic variation in GLP1R impacted the response to different SGAs, finding that different patient haplotypes had different responses to SGAs, but were not associated with AIWG [162]. A better understanding of the physiological impact of these GLP1R variants might highlight insulin and glucose disturbances associated with the treatments. The CATIE trial also evaluated 106 single-nucleotide polymorphisms in synaptic vesicle protein 2 (SV2C), also implicated in glucose-dependent insulin release, finding that four of them correlated with olanzapine and quetiapine response [163]. Furthermore, haplotypes in the serotonin receptor HTR2A [-1438A, -783A, 102T, and 452Tyr] had a protective effect against the clozapine and olanzapine-mediated increase in C-peptide levels [164].

In another study analyzing DNA methylation changes in candidate genes, Burghardt and colleagues [165] used epigenome-wide association studies to identify a hypomethylated CpG site in fatty acyl Coa reductase 2 (FAR2) associated with insulin resistance as measured by homeostatic model assessment. Also, single-nucleotide polymorphisms in the melacortin 4 receptor (MC4R), a common biomarker for predicting individual susceptibility to weight gain and obesity, have been linked to SGA-induced MetS [166]. Another potential genetic determinant is the 5- $\mathrm{HT}_{2} \mathrm{C}$ receptor $(H T 2 R C)$, which has been previously associated with feeding behavior and weight gain and which is antagonized by clozapine and olanzapine. Mulder and collaborators [167] reported an association between several polymorphisms at HT2RC (HTR2C:c.1-142948(GT)n, rs518147 (-697 G/C), and rs1414334) and an increased risk for MetS in patients treated with olanzapine, risperidone or clozapine. An association between MetS and HT2RC has also been proposed in other studies. For example, the rs498177 variant showed a significant association with MetS in female patients treated with olanzapine or risperidone [168], and the same was found for the rs518147CC and rs12836771GG variants in patients [169]. Although the contribution of HT2RC to MetS can be because of AIWG, we cannot rule-out the dysregulation of glucose metabolism. A recent study comparing the gene expression patterns in blood samples between first-episode, drug-naïve patients with schizophrenia with weight gain after 3 months of treatment with risperidone or aripiprazole with those of patients that did not gain weight reported an enrichment of genes involved in immune system pathways in the former, highlighting the role of inflammation in the metabolic disturbances associated with SGAs [170]. Moreover, a study addressing the clinical response to clozapine found genetic variability in two genes involved in the hypothalamic-pituitary-adrenal axis: FKBP5 (encoding for FK506 binding protein 5) and NTRK2 (encoding for neurotrophic tyrosine kinase receptor 2). It is possible that this genetic variability might be responsible for the key role of the CNS in mediating the metabolic side-effects of SGAs [171]. Finally, it is noteworthy to mention that, in the last years, microRNAs (miRNAs), which have emerged as important post-transcriptional regulators of gene expression, have been involved in the occurrence of neurological disorders including schizophrenia [172]. Among them, miRNA-9 and miRNA-326 are regulators of human DRD2 expression in human dopaminergic neurons [173]. Of relevance, a recent study has revealed that the combination of miRNA-22-3p, miRNA-92a-3p, and miRNA-137, detected in peripheral blood, was closely associated with schizophrenia [174]. A step further, the decrease of miRNA-21 expression found in patients treated with olanzapine, quetiapine, ziprasidone or risperidone [175], points to possible changes in circulating miRNAs expression in response to antipsychotic medication for schizophrenia although the molecular mechanisms beyond of this need further research.

\section{Concluding Remarks}

Antipsychotics, especially SGAs, are associated with weight gain and glucose dysregulation, two major contributors to T2D development. While AIWG is associated with glucose dysregulation, evidence points to a direct effect of SGAs on glucose metabolism. In this review, we have addressed how diabetogenic SGAs, in particular olanzapine and clozapine, but also the FGA chlorpromazine, can impair insulin signaling in insulin-sensitive tissues, such as liver and skeletal muscle, interfering with glucose transport, glycogen synthesis and gluconeogenesis and, consequently, inducing insulin resistance (Table 1). Importantly, SGAs have a direct effect on $\beta$-cell function and insulin secretion 
and probably also on $\alpha$-cells and associated glucagon secretion (Table 1). Overall, the development of insulin resistance and the impact on $\beta$-cell function associated with antipsychotics, especially SGAs, can explain the diabetogenic effects associated with treatment. Moreover, the existence of different polymorphisms in the human population likely explains the different susceptibility of patients with schizophrenia to the metabolic side-effects of SGAs.

Table 1. List of mentioned APDs effects on peripheral insulin-sensitive tissues inducing dysregulation in glucose homeostasis.

\begin{tabular}{|c|c|c|}
\hline Pharmacological Target & Antipsychotics Mentioned in this Review & Effect in Insulin-Sensitive Tissue \\
\hline \multirow{4}{*}{ H1R antagonism } & Olanzapine, clozapine & $\begin{array}{l}\text { Hepatic insulin signaling impairment } \\
{[73,114,117,119-122]}\end{array}$ \\
\hline & Olanzapine & Hepatic AMPK signaling impairment $[115,124]$ \\
\hline & Olanzapine & Skeletal muscle AMPK signaling impairment [74] \\
\hline & Olanzapine, clozapine, quetiapine & Skeletal muscle insulin signaling impairment $[77,135]$ \\
\hline 5-HT 1 agonism & Olanzapine & $\downarrow$ Hepatic glycogen synthesis [67] \\
\hline \multirow{2}{*}{ 5- $\mathrm{HT}_{2} \mathrm{~A}$ antagonism } & Olanzapine & $\downarrow$ Hepatic glycogen synthesis $[67,105,110]$ \\
\hline & Quetiapine & $\downarrow$ Skeletal muscle glucose uptake [77] \\
\hline \multirow{3}{*}{ D2R antagonism } & $\begin{array}{l}\text { Haloperidol, sulpiride, olanzapine, } \\
\text { clozapine }\end{array}$ & $\uparrow$ Glucose-Stimulated Insulin Secretion $[85,92]$ \\
\hline & Clozapine & $\uparrow$ Basal insulin secretion $[90,91]$ \\
\hline & Chlorpromazine & Hepatic insulin signaling impairment [100] \\
\hline M3R antagonism & Clozapine, olanzapine & $\downarrow$ Insulin secretion $[95,96]$ \\
\hline \multirow{4}{*}{ Unknown } & Clozapine, olanzapine, quetiapine & $\uparrow$ Glucagon secretion $[92,146,148]$ \\
\hline & Clozapine, quetiapine & $\downarrow$ GLP-1 levels [146] \\
\hline & Olanzapine & $\downarrow$ Skeletal muscle glycogen synthesis [71] \\
\hline & & $\downarrow$ Skeletal muscle glucose uptake [72] \\
\hline
\end{tabular}

Funding: This work was funded by the grant H2020 Marie Sklodowska-Curie ITN-TREATMENT (Grant Agreement 721236, European Commission). We also acknowledge grants RTI2018-094052-B-100 (MICINN/FEDER, Spain), S2017/BMD-3684 MOIR2-CM (Comunidad de Madrid, Spain) and CIBERdem (ISCIII, Spain).

Conflicts of Interest: The authors declare no conflict of interest.

\section{References}

1. Carton, L.; Cottencin, O.; Lapeyre-Mestre, M.; Geoffroy, P.A.; Favre, J.; Simon, N.; Bordet, R.; Rolland, B. Off-Label Prescribing of Antipsychotics in Adults, Children and Elderly Individuals: A Systematic Review of Recent Prescription Trends. Curr. Pharm. Des. 2015, 21, 3280-3297. [CrossRef] [PubMed]

2. Lauriello, J.; Perkins, D.O. Enhancing the Treatment of Patients With Schizophrenia Through Continuous Care. J. Clin. Psychiatry 2019, 80. [CrossRef] [PubMed]

3. Nesvag, R.; Hartz, I.; Bramness, J.G.; Hjellvik, V.; Handal, M.; Skurtveit, S. Mental disorder diagnoses among children and adolescents who use antipsychotic drugs. Eur. Neuropsychopharmacol. 2016, 26, 1412-1418. [CrossRef] [PubMed]

4. Ban, T.A. Fifty years chlorpromazine: A historical perspective. Neuropsychiatr. Dis. Treat. 2007, 3, 495-500. [PubMed]

5. Shen, W.W. A history of antipsychotic drug development. Compr. Psychiatry 1999, 40, 407-414. [CrossRef]

6. Seeman, P. Clozapine, a fast-off-D2 antipsychotic. ACS Chem. Neurosci. 2014, 5, 24-29. [CrossRef]

7. Nucifora, F.C., Jr.; Mihaljevic, M.; Lee, B.J.; Sawa, A. Clozapine as a Model for Antipsychotic Development. Neurotherapeutics 2017, 14, 750-761. [CrossRef]

8. Mailman, R.B.; Murthy, V. Third generation antipsychotic drugs: Partial agonism or receptor functional selectivity? Curr. Pharm. Des. 2010, 16, 488-501. [CrossRef]

9. Tuplin, E.W.; Holahan, M.R. Aripiprazole, A Drug that Displays Partial Agonism and Functional Selectivity. Curr. Neuropharmacol. 2017, 15, 1192-1207. [CrossRef]

10. De Greef, R.; Maloney, A.; Olsson-Gisleskog, P.; Schoemaker, J.; Panagides, J. Dopamine D2 occupancy as a biomarker for antipsychotics: Quantifying the relationship with efficacy and extrapyramidal symptoms. AAPS J. 2011, 13, 121-130. [CrossRef] 
11. Yilmaz, Z.; Zai, C.C.; Hwang, R.; Mann, S.; Arenovich, T.; Remington, G.; Daskalakis, Z.J. Antipsychotics, dopamine $\mathrm{D}(2)$ receptor occupancy and clinical improvement in schizophrenia: A meta-analysis. Schizophr. Res. 2012, 140, 214-220. [CrossRef]

12. Nordstrom, A.L.; Farde, L. Plasma prolactin and central D2 receptor occupancy in antipsychotic drug-treated patients. J. Clin. Psychopharmacol. 1998, 18, 305-310. [CrossRef] [PubMed]

13. Pani, L.; Pira, L.; Marchese, G. Antipsychotic efficacy: Relationship to optimal D2-receptor occupancy. Eur. Psychiatry 2007, 22, 267-275. [CrossRef] [PubMed]

14. Sykes, D.A.; Moore, H.; Stott, L.; Holliday, N.; Javitch, J.A.; Lane, J.R.; Charlton, S.J. Extrapyramidal side effects of antipsychotics are linked to their association kinetics at dopamine D2 receptors. Nat. Commun. 2017, 8, 763. [CrossRef] [PubMed]

15. Miyamoto, S.; Duncan, G.E.; Marx, C.E.; Lieberman, J.A. Treatments for schizophrenia: A critical review of pharmacology and mechanisms of action of antipsychotic drugs. Mol. Psychiatry 2005, 10, 79-104. [CrossRef] [PubMed]

16. Mauri, M.C.; Paletta, S.; Maffini, M.; Colasanti, A.; Dragogna, F.; Di Pace, C.; Altamura, A.C. Clinical pharmacology of atypical antipsychotics: An update. EXCLI J. 2014, 13, 1163-1191.

17. Kusumi, I.; Boku, S.; Takahashi, Y. Psychopharmacology of atypical antipsychotic drugs: From the receptor binding profile to neuroprotection and neurogenesis. Psychiatry Clin. Neurosci. 2015, 69, 243-258. [CrossRef]

18. Brown, S. Excess mortality of schizophrenia. A meta-analysis. Br. J. Psychiatry 1997, 171, 502-508. [CrossRef]

19. Correll, C.U.; Solmi, M.; Veronese, N.; Bortolato, B.; Rosson, S.; Santonastaso, P.; Thapa-Chhetri, N.; Fornaro, M.; Gallicchio, D.; Collantoni, E.; et al. Prevalence, incidence and mortality from cardiovascular disease in patients with pooled and specific severe mental illness: A large-scale meta-analysis of 3,211,768 patients and 113,383,368 controls. World Psychiatry 2017, 16, 163-180. [CrossRef]

20. Westman, J.; Eriksson, S.V.; Gissler, M.; Hallgren, J.; Prieto, M.L.; Bobo, W.V.; Frye, M.A.; Erlinge, D.; Alfredsson, L.; Osby, U. Increased cardiovascular mortality in people with schizophrenia: A 24-year national register study. Epidemiol. Psychiatr. Sci. 2018, 27, 519-527. [CrossRef]

21. Hayes, J.F.; Marston, L.; Walters, K.; King, M.B.; Osborn, D.P.J. Mortality gap for people with bipolar disorder and schizophrenia: UK-based cohort study 2000-2014. Br. J. Psychiatry 2017, 211, 175-181. [CrossRef] [PubMed]

22. Annamalai, A.; Kosir, U.; Tek, C. Prevalence of obesity and diabetes in patients with schizophrenia. World J. Diabetes 2017, 8, 390-396. [CrossRef] [PubMed]

23. Cather, C.; Pachas, G.N.; Cieslak, K.M.; Evins, A.E. Achieving Smoking Cessation in Individuals with Schizophrenia: Special Considerations. CNS Drugs 2017, 31, 471-481. [CrossRef] [PubMed]

24. Ratliff, J.C.; Palmese, L.B.; Reutenauer, E.L.; Liskov, E.; Grilo, C.M.; Tek, C. The effect of dietary and physical activity pattern on metabolic profile in individuals with schizophrenia: A cross-sectional study. Compr. Psychiatry 2012, 53, 1028-1033. [CrossRef] [PubMed]

25. Vancampfort, D.; Correll, C.U.; Galling, B.; Probst, M.; De Hert, M.; Ward, P.B.; Rosenbaum, S.; Gaughran, F.; Lally, J.; Stubbs, B. Diabetes mellitus in people with schizophrenia, bipolar disorder and major depressive disorder: A systematic review and large scale meta-analysis. World Psychiatry 2016, 15, 166-174. [CrossRef]

26. Gatov, E.; Rosella, L.; Chiu, M.; Kurdyak, P.A. Trends in standardized mortality among individuals with schizophrenia, 1993-2012: A population-based, repeated cross-sectional study. CMAJ 2017, 189, E1177-E1187. [CrossRef]

27. Fleischhacker, W.W.; Siu, C.O.; Boden, R.; Pappadopulos, E.; Karayal, O.N.; Kahn, R.S.; EUFEST Study Group. Metabolic risk factors in first-episode schizophrenia: Baseline prevalence and course analysed from the European First-Episode Schizophrenia Trial. Int. J. Neuropsychopharmacol. 2013, 16, 987-995. [CrossRef]

28. Vancampfort, D.; Wampers, M.; Mitchell, A.J.; Correll, C.U.; De Herdt, A.; Probst, M.; De Hert, M. A meta-analysis of cardio-metabolic abnormalities in drug naive, first-episode and multi-episode patients with schizophrenia versus general population controls. World Psychiatry 2013, 12, 240-250. [CrossRef]

29. Venkatasubramanian, G.; Chittiprol, S.; Neelakantachar, N.; Naveen, M.N.; Thirthall, J.; Gangadhar, B.N.; Shetty, K.T. Insulin and insulin-like growth factor-1 abnormalities in antipsychotic-naive schizophrenia. Am. J. Psychiatry 2007, 164, 1557-1560. [CrossRef]

30. Li, Z.; Chen, P.; Chen, J.; Xu, Y.; Wang, Q.; Li, X.; Li, C.; He, L.; Shi, Y. Glucose and Insulin-Related Traits, Type 2 Diabetes and Risk of Schizophrenia: A Mendelian Randomization Study. EBioMedicine 2018, 34, 182-188. [CrossRef] 
31. Pillinger, T.; Beck, K.; Gobjila, C.; Donocik, J.G.; Jauhar, S.; Howes, O.D. Impaired Glucose Homeostasis in First-Episode Schizophrenia: A Systematic Review and Meta-analysis. JAMA Psychiatry 2017, 74, 261-269. [CrossRef] [PubMed]

32. Perry, B.I.; McIntosh, G.; Weich, S.; Singh, S.; Rees, K. The association between first-episode psychosis and abnormal glycaemic control: Systematic review and meta-analysis. Lancet Psychiatry 2016, 3, 1049-1058. [CrossRef]

33. Liu, Y.; Li, Z.; Zhang, M.; Deng, Y.; Yi, Z.; Shi, T. Exploring the pathogenetic association between schizophrenia and type 2 diabetes mellitus diseases based on pathway analysis. BMC Med. Genom. 2013, 6 (Suppl. S1), S17. [CrossRef]

34. Maciukiewicz, M.; Gorbovskaya, I.; Tiwari, A.K.; Zai, C.C.; Freeman, N.; Meltzer, H.Y.; Kennedy, J.L.; Muller, D.J. Genetic validation study of protein tyrosine phosphatase receptor type D (PTPRD) gene variants and risk for antipsychotic-induced weight gain. J. Neural Transm. (Vienna) 2019, 126, 27-33. [CrossRef] [PubMed]

35. Cao, H.; Chen, J.; Meyer-Lindenberg, A.; Schwarz, E. A polygenic score for schizophrenia predicts glycemic control. Transl. Psychiatry 2017, 7, 1295. [CrossRef]

36. Padmanabhan, J.L.; Nanda, P.; Tandon, N.; Mothi, S.S.; Bolo, N.; McCarroll, S.; Clementz, B.A.; Gershon, E.S.; Pearlson, G.D.; Sweeney, J.A.; et al. Polygenic risk for type 2 diabetes mellitus among individuals with psychosis and their relatives. J. Psychiatr. Res. 2016, 77, 52-58. [CrossRef]

37. Polimanti, R.; Gelernter, J.; Stein, D.J. Genetically determined schizophrenia is not associated with impaired glucose homeostasis. Schizophr. Res. 2018, 195, 286-289. [CrossRef]

38. Correll, C.U.; Manu, P.; Olshanskiy, V.; Napolitano, B.; Kane, J.M.; Malhotra, A.K. Cardiometabolic risk of second-generation antipsychotic medications during first-time use in children and adolescents. JAMA 2009, 302, 1765-1773. [CrossRef]

39. Sjo, C.P.; Stenstrom, A.D.; Bojesen, A.B.; Frolich, J.S.; Bilenberg, N. Development of Metabolic Syndrome in Drug-Naive Adolescents After 12 Months of Second-Generation Antipsychotic Treatment. J. Child. Adolesc. Psychopharmacol. 2017, 27, 884-891. [CrossRef]

40. Polcwiartek, C.; Kragholm, K.; Rohde, C.; Hashemi, N.; Vang, T.; Nielsen, J. Diabetic ketoacidosis and diabetes associated with antipsychotic exposure among a previously diabetes-naive population with schizophrenia: A nationwide nested case-control study. Diabetologia 2017, 60, 1678-1690. [CrossRef]

41. Rajkumar, A.P.; Horsdal, H.T.; Wimberley, T.; Cohen, D.; Mors, O.; Borglum, A.D.; Gasse, C. Endogenous and Antipsychotic-Related Risks for Diabetes Mellitus in Young People With Schizophrenia: A Danish Population-Based Cohort Study. Am. J. Psychiatry 2017, 174, 686-694. [CrossRef] [PubMed]

42. Nielsen, J.; Skadhede, S.; Correll, C.U. Antipsychotics associated with the development of type 2 diabetes in antipsychotic-naive schizophrenia patients. Neuropsychopharmacology 2010, 35, 1997-2004. [CrossRef] [PubMed]

43. Saiz-Rodriguez, M.; Belmonte, C.; Roman, M.; Ochoa, D.; Jiang-Zheng, C.; Koller, D.; Mejia, G.; Zubiaur, P.; Wojnicz, A.; Abad-Santos, F. Effect of ABCB1 C3435T Polymorphism on Pharmacokinetics of Antipsychotics and Antidepressants. Basic Clin. Pharmacol. Toxicol. 2018, 123, 474-485. [CrossRef] [PubMed]

44. Chiliza, B.; Asmal, L.; Oosthuizen, P.; van Niekerk, E.; Erasmus, R.; Kidd, M.; Malhotra, A.; Emsley, R. Changes in body mass and metabolic profiles in patients with first-episode schizophrenia treated for 12 months with a first-generation antipsychotic. Eur. Psychiatry 2015, 30, 277-283. [CrossRef]

45. Chadda, R.K.; Ramshankar, P.; Deb, K.S.; Sood, M. Metabolic syndrome in schizophrenia: Differences between antipsychotic-naive and treated patients. J. Pharmacol. Pharmacother. 2013, 4, 176-186. [CrossRef]

46. Sapra, M.; Lawson, D.; Iranmanesh, A. Fat Distribution in Schizophrenia Patients: A Pilot Study Comparing First- and Second-Generation Antipsychotics. J. Clin. Psychopharmacol. 2018, 38, 68-71. [CrossRef]

47. Ingimarsson, O.; MacCabe, J.H.; Haraldsson, M.; Jonsdottir, H.; Sigurdsson, E. Risk of diabetes and dyslipidemia during clozapine and other antipsychotic drug treatment of schizophrenia in Iceland. Nord. J. Psychiatry 2017, 71, 496-502. [CrossRef]

48. Sacher, J.; Mossaheb, N.; Spindelegger, C.; Klein, N.; Geiss-Granadia, T.; Sauermann, R.; Lackner, E.; Joukhadar, C.; Muller, M.; Kasper, S. Effects of olanzapine and ziprasidone on glucose tolerance in healthy volunteers. Neuropsychopharmacology 2008, 33, 1633-1641. [CrossRef] 
49. Teff, K.L.; Rickels, M.R.; Grudziak, J.; Fuller, C.; Nguyen, H.L.; Rickels, K. Antipsychotic-induced insulin resistance and postprandial hormonal dysregulation independent of weight gain or psychiatric disease. Diabetes 2013, 62, 3232-3240. [CrossRef]

50. Albaugh, V.L.; Singareddy, R.; Mauger, D.; Lynch, C.J. A double blind, placebo-controlled, randomized crossover study of the acute metabolic effects of olanzapine in healthy volunteers. PLoS ONE 2011, 6, e22662. [CrossRef]

51. Daurignac, E.; Leonard, K.E.; Dubovsky, S.L. Increased lean body mass as an early indicator of olanzapine-induced weight gain in healthy men. Int. Clin. Psychopharmacol. 2015, 30, 23-28. [CrossRef] [PubMed]

52. Burghardt, K.J.; Seyoum, B.; Mallisho, A.; Burghardt, P.R.; Kowluru, R.A.; Yi, Z. Atypical antipsychotics, insulin resistance and weight; a meta-analysis of healthy volunteer studies. Prog. Neuropsychopharmacol. Biol. Psychiatry 2018, 83, 55-63. [CrossRef] [PubMed]

53. Tek, C.; Kucukgoncu, S.; Guloksuz, S.; Woods, S.W.; Srihari, V.H.; Annamalai, A. Antipsychotic-induced weight gain in first-episode psychosis patients: A meta-analysis of differential effects of antipsychotic medications. Early Interv. Psychiatry 2016, 10, 193-202. [CrossRef] [PubMed]

54. Cuerda, C.; Velasco, C.; Merchan-Naranjo, J.; Garcia-Peris, P.; Arango, C. The effects of second-generation antipsychotics on food intake, resting energy expenditure and physical activity. Eur. J. Clin. Nutr. 2014, 68, 146-152. [CrossRef] [PubMed]

55. Salvi, V.; Mencacci, C.; Barone-Adesi, F. H1-histamine receptor affinity predicts weight gain with antidepressants. Eur. Neuropsychopharmacol. 2016, 26, 1673-1677. [CrossRef] [PubMed]

56. Hong, K.S.; Park, T. Searching susceptibility genes for antipsychotic-induced weight gain: Is the 5-HT2C receptor gene a promising candidate? Pers. Med. 2007, 4, 357-361. [CrossRef]

57. Templeman, L.A.; Reynolds, G.P.; Arranz, B.; San, L. Polymorphisms of the 5-HT2C receptor and leptin genes are associated with antipsychotic drug-induced weight gain in Caucasian subjects with a first-episode psychosis. Pharmacogenet. Genom. 2005, 15, 195-200. [CrossRef]

58. Baik, J.H. Dopamine signaling in food addiction: Role of dopamine D2 receptors. BMB Rep. 2013, 46, 519-526. [CrossRef]

59. Coleman, R.A.; Mashek, D.G. Mammalian triacylglycerol metabolism: Synthesis, lipolysis, and signaling. Chem. Rev. 2011, 111, 6359-6386. [CrossRef]

60. Canfran-Duque, A.; Casado, M.E.; Pastor, O.; Sanchez-Wandelmer, J.; de la Pena, G.; Lerma, M.; Mariscal, P.; Bracher, F.; Lasuncion, M.A.; Busto, R. Atypical antipsychotics alter cholesterol and fatty acid metabolism in vitro. J. Lipid Res. 2013, 54, 310-324. [CrossRef]

61. Ferno, J.; Raeder, M.B.; Vik-Mo, A.O.; Skrede, S.; Glambek, M.; Tronstad, K.J.; Breilid, H.; Lovlie, R.; Berge, R.K.; Stansberg, C.; et al. Antipsychotic drugs activate SREBP-regulated expression of lipid biosynthetic genes in cultured human glioma cells: A novel mechanism of action? Pharm. J. 2005, 5, 298-304. [CrossRef] [PubMed]

62. Catafau, A.M.; Penengo, M.M.; Nucci, G.; Bullich, S.; Corripio, I.; Parellada, E.; Garcia-Ribera, C.; Gomeni, R.; Merlo-Pich, E.; Barcelona Clinical Imaging in Psychiatry Group. Pharmacokinetics and time-course of D(2) receptor occupancy induced by atypical antipsychotics in stabilized schizophrenic patients. J. Psychopharmacol. 2008, 22, 882-894. [CrossRef] [PubMed]

63. Aravagiri, M.; Teper, Y.; Marder, S.R. Pharmacokinetics and tissue distribution of olanzapine in rats. Biopharm. Drug Dispos. 1999, 20, 369-377. [CrossRef]

64. Ikemura, M.; Nakagawa, Y.; Shinone, K.; Inoue, H.; Nata, M. The blood concentration and organ distribution of haloperidol at therapeutic and toxic doses in severe fatty liver disease. Leg. Med. (Tokyo) 2012, 14, 147-153. [CrossRef] [PubMed]

65. Han, H.S.; Kang, G.; Kim, J.S.; Choi, B.H.; Koo, S.H. Regulation of glucose metabolism from a liver-centric perspective. Exp. Mol. Med. 2016, 48, e218. [CrossRef]

66. Tudhope, S.J.; Wang, C.C.; Petrie, J.L.; Potts, L.; Malcomson, F.; Kieswich, J.; Yaqoob, M.M.; Arden, C.; Hampson, L.J.; Agius, L. A novel mechanism for regulating hepatic glycogen synthesis involving serotonin and cyclin-dependent kinase-5. Diabetes 2012, 61, 49-60. [CrossRef]

67. Hampson, L.J.; Mackin, P.; Agius, L. Stimulation of glycogen synthesis and inactivation of phosphorylase in hepatocytes by serotonergic mechanisms, and counter-regulation by atypical antipsychotic drugs. Diabetologia 2007, 50, 1743-1751. [CrossRef] 
68. Contreras-Shannon, V.; Heart, D.L.; Paredes, R.M.; Navaira, E.; Catano, G.; Maffi, S.K.; Walss-Bass, C. Clozapine-induced mitochondria alterations and inflammation in brain and insulin-responsive cells. PLOS ONE 2013, 8, e59012. [CrossRef]

69. Eftekhari, A.; Azarmi, Y.; Parvizpur, A.; Eghbal, M.A. Involvement of oxidative stress and mitochondrial/lysosomal cross-talk in olanzapine cytotoxicity in freshly isolated rat hepatocytes. Xenobiotica 2016, 46, 369-378. [CrossRef]

70. Eftekhari, A.; Ahmadian, E.; Azarmi, Y.; Parvizpur, A.; Hamishehkar, H.; Eghbal, M.A. In vitro/vivo studies towards mechanisms of risperidone-induced oxidative stress and the protective role of coenzyme Q10 and N-acetylcysteine. Toxicol. Mech. Methods 2016, 26, 520-528. [CrossRef]

71. Engl, J.; Laimer, M.; Niederwanger, A.; Kranebitter, M.; Starzinger, M.; Pedrini, M.T.; Fleischhacker, W.W.; Patsch, J.R.; Ebenbichler, C.F. Olanzapine impairs glycogen synthesis and insulin signaling in L6 skeletal muscle cells. Mol. Psychiatry 2005, 10, 1089-1096. [CrossRef] [PubMed]

72. Panariello, F.; Perruolo, G.; Cassese, A.; Giacco, F.; Botta, G.; Barbagallo, A.P.; Muscettola, G.; Beguinot, F.; Formisano, P.; de Bartolomeis, A. Clozapine impairs insulin action by up-regulating Akt phosphorylation and Ped/Pea-15 protein abundance. J. Cell. Physiol. 2012, 227, 1485-1492. [CrossRef] [PubMed]

73. Tulipano, G.; Spano, P.; Cocchi, D. Effects of olanzapine on glucose transport, proliferation and survival in C2C12 myoblasts. Mol. Cell. Endocrinol. 2008, 292, 42-49. [CrossRef] [PubMed]

74. Kim, J.H.; Lee, J.O.; Lee, S.K.; Jung, J.H.; You, G.Y.; Park, S.H.; Park, M.; Kim, S.D.; Kim, H.S. Clozapine activates AMP-activated protein kinase (AMPK) in C2C12 myotube cells and stimulates glucose uptake. Life Sci. 2010, 87, 42-48. [CrossRef]

75. Tulipano, G.; Rizzetti, C.; Bianchi, I.; Fanzani, A.; Spano, P.; Cocchi, D. Clozapine-induced alteration of glucose homeostasis in the rat: The contribution of hypothalamic-pituitary-adrenal axis activation. Neuroendocrinology 2007, 85, 61-70. [CrossRef]

76. Ardizzone, T.D.; Bradley, R.J.; Freeman, A.M., 3rd; Dwyer, D.S. Inhibition of glucose transport in PC12 cells by the atypical antipsychotic drugs risperidone and clozapine, and structural analogs of clozapine. Brain Res. 2001, 923, 82-90. [CrossRef]

77. Nagashima, T.; Shirakawa, H.; Nakagawa, T.; Kaneko, S. Prevention of antipsychotic-induced hyperglycaemia by vitamin D: A data mining prediction followed by experimental exploration of the molecular mechanism. Sci. Rep. 2016, 6, 26375. [CrossRef]

78. Smith, G.C.; Chaussade, C.; Vickers, M.; Jensen, J.; Shepherd, P.R. Atypical antipsychotic drugs induce derangements in glucose homeostasis by acutely increasing glucagon secretion and hepatic glucose output in the rat. Diabetologia 2008, 51, 2309-2317. [CrossRef]

79. Al-Zoairy, R.; Ress, C.; Tschoner, A.; Kaser, S.; Ebenbichler, C. The effects of psychotropic drugs on the regulation of glucose metabolism. Curr. Diabetes Rev. 2013, 9, 362-370. [CrossRef]

80. Babkin, P.; George Thompson, A.M.; Iancu, C.V.; Walters, D.E.; Choe, J.Y. Antipsychotics inhibit glucose transport: Determination of olanzapine binding site in Staphylococcus epidermidis glucose $/ \mathrm{H}(+)$ symporter. FEBS Open Bio. 2015, 5, 335-340. [CrossRef]

81. Ustione, A.; Piston, D.W. Dopamine synthesis and D3 receptor activation in pancreatic beta-cells regulates insulin secretion and intracellular [Ca(2+)] oscillations. Mol. Endocrinol. 2012, 26, 1928-1940. [CrossRef] [PubMed]

82. Ganic, E.; Johansson, J.K.; Bennet, H.; Fex, M.; Artner, I. Islet-specific monoamine oxidase A and B expression depends on MafA transcriptional activity and is compromised in type 2 diabetes. Biochem. Biophys. Res. Commun. 2015, 468, 629-635. [CrossRef] [PubMed]

83. Farino, Z.J.; Morgenstern, T.J.; Maffei, A.; Quick, M.; De Solis, A.J.; Wiriyasermkul, P.; Freyberg, R.J.; Aslanoglou, D.; Sorisio, D.; Inbar, B.P.; et al. New roles for dopamine D2 and D3 receptors in pancreatic beta cell insulin secretion. Mol. Psychiatry 2019. [CrossRef] [PubMed]

84. Rubi, B.; Ljubicic, S.; Pournourmohammadi, S.; Carobbio, S.; Armanet, M.; Bartley, C.; Maechler, P. Dopamine D2-like receptors are expressed in pancreatic beta cells and mediate inhibition of insulin secretion. J. Biol. Chem. 2005, 280, 36824-36832. [CrossRef]

85. Simpson, N.; Maffei, A.; Freeby, M.; Burroughs, S.; Freyberg, Z.; Javitch, J.; Leibel, R.L.; Harris, P.E. Dopamine-mediated autocrine inhibitory circuit regulating human insulin secretion in vitro. Mol. Endocrinol. 2012, 26, 1757-1772. [CrossRef] 
86. Cataldo Bascunan, L.R.; Lyons, C.; Bennet, H.; Artner, I.; Fex, M. Serotonergic regulation of insulin secretion. Acta Physiol. (Oxf.) 2019, 225, e13101. [CrossRef]

87. Bennet, H.; Mollet, I.G.; Balhuizen, A.; Medina, A.; Nagorny, C.; Bagge, A.; Fadista, J.; Ottosson-Laakso, E.; Vikman, P.; Dekker-Nitert, M.; et al. Serotonin (5-HT) receptor $2 \mathrm{~b}$ activation augments glucose-stimulated insulin secretion in human and mouse islets of Langerhans. Diabetologia 2016, 59, 744-754. [CrossRef]

88. Weston-Green, K.; Huang, X.F.; Lian, J.; Deng, C. Effects of olanzapine on muscarinic M3 receptor binding density in the brain relates to weight gain, plasma insulin and metabolic hormone levels. Eur. Neuropsychopharmacol. 2012, 22, 364-373. [CrossRef]

89. Nakajima, K.; Jain, S.; Ruiz de Azua, I.; McMillin, S.M.; Rossi, M.; Wess, J. Minireview: Novel aspects of M3 muscarinic receptor signaling in pancreatic beta-cells. Mol. Endocrinol. 2013, 27, 1208-1216. [CrossRef]

90. Melkersson, K.; Khan, A.; Hilding, A.; Hulting, A.L. Different effects of antipsychotic drugs on insulin release in vitro. Eur. Neuropsychopharmacol. 2001, 11, 327-332. [CrossRef]

91. Melkersson, K. Clozapine and olanzapine, but not conventional antipsychotics, increase insulin release in vitro. Eur. Neuropsychopharmacol. 2004, 14, 115-119. [CrossRef]

92. Smith, G.C.; Zhang, Z.Y.; Mulvey, T.; Petersen, N.; Lach, S.; Xiu, P.; Phillips, A.; Han, W.; Wang, M.W.; Shepherd, P.R. Clozapine directly increases insulin and glucagon secretion from islets: Implications for impairment of glucose tolerance. Schizophr. Res. 2014, 157, 128-133. [CrossRef] [PubMed]

93. Menga, A.; Infantino, V.; Iacobazzi, F.; Convertini, P.; Palmieri, F.; Iacobazzi, V. Insight into mechanism of in vitro insulin secretion increase induced by antipsychotic clozapine: Role of FOXA1 and mitochondrial citrate carrier. Eur. Neuropsychopharmacol. 2013, 23, 978-987. [CrossRef] [PubMed]

94. Melkersson, K.I.; Dahl, M.L. Relationship between levels of insulin or triglycerides and serum concentrations of the atypical antipsychotics clozapine and olanzapine in patients on treatment with therapeutic doses. Psychopharmacology 2003, 170, 157-166. [CrossRef]

95. Johnson, D.E.; Yamazaki, H.; Ward, K.M.; Schmidt, A.W.; Lebel, W.S.; Treadway, J.L.; Gibbs, E.M.; Zawalich, W.S.; Rollema, H. Inhibitory effects of antipsychotics on carbachol-enhanced insulin secretion from perifused rat islets: Role of muscarinic antagonism in antipsychotic-induced diabetes and hyperglycemia. Diabetes 2005, 54, 1552-1558. [CrossRef]

96. Sasaki, N.; Iwase, M.; Uchizono, Y.; Nakamura, U.; Imoto, H.; Abe, S.; Iida, M. The atypical antipsychotic clozapine impairs insulin secretion by inhibiting glucose metabolism and distal steps in rat pancreatic islets. Diabetologia 2006, 49, 2930-2938. [CrossRef]

97. Best, L.; Yates, A.P.; Reynolds, G.P. Actions of antipsychotic drugs on pancreatic beta-cell function: Contrasting effects of clozapine and haloperidol. J. Psychopharmacol. 2005, 19, 597-601. [CrossRef]

98. Ozasa, R.; Okada, T.; Nadanaka, S.; Nagamine, T.; Zyryanova, A.; Harding, H.; Ron, D.; Mori, K. The antipsychotic olanzapine induces apoptosis in insulin-secreting pancreatic beta cells by blocking PERK-mediated translational attenuation. Cell Struct. Funct. 2013, 38, 183-195. [CrossRef]

99. Park, S.; Hong, S.M.; Lee, J.E.; Sung, S.R.; Kim, S.H. Chlorpromazine attenuates pancreatic beta-cell function and mass through IRS2 degradation, while exercise partially reverses the attenuation. J. Psychopharmacol. 2008, 22, 522-531. [CrossRef]

100. Albaugh, V.L.; Henry, C.R.; Bello, N.T.; Hajnal, A.; Lynch, S.L.; Halle, B.; Lynch, C.J. Hormonal and metabolic effects of olanzapine and clozapine related to body weight in rodents. Obesity (Silver Spring) 2006, 14, 36-51. [CrossRef]

101. Davey, K.J.; O’Mahony, S.M.; Schellekens, H.; O'Sullivan, O.; Bienenstock, J.; Cotter, P.D.; Dinan, T.G.; Cryan, J.F. Gender-dependent consequences of chronic olanzapine in the rat: Effects on body weight, inflammatory, metabolic and microbiota parameters. Psychopharmacology 2012, 221, 155-169. [CrossRef] [PubMed]

102. Klingerman, C.M.; Stipanovic, M.E.; Bader, M.; Lynch, C.J. Second-generation antipsychotics cause a rapid switch to fat oxidation that is required for survival in C57BL/6J mice. Schizophr. Bull. 2014, 40, 327-340. [CrossRef] [PubMed]

103. Castellani, L.N.; Peppler, W.T.; Sutton, C.D.; Whitfield, J.; Charron, M.J.; Wright, D.C. Glucagon receptor knockout mice are protected against acute olanzapine-induced hyperglycemia. Psychoneuroendocrinology 2017, 82, 38-45. [CrossRef] 
104. Albaugh, V.L.; Vary, T.C.; Ilkayeva, O.; Wenner, B.R.; Maresca, K.P.; Joyal, J.L.; Breazeale, S.; Elich, T.D.; Lang, C.H.; Lynch, C.J. Atypical antipsychotics rapidly and inappropriately switch peripheral fuel utilization to lipids, impairing metabolic flexibility in rodents. Schizophr. Bull. 2012, 38, 153-166. [CrossRef] [PubMed]

105. Houseknecht, K.L.; Robertson, A.S.; Zavadoski, W.; Gibbs, E.M.; Johnson, D.E.; Rollema, H. Acute effects of atypical antipsychotics on whole-body insulin resistance in rats: Implications for adverse metabolic effects. Neuropsychopharmacology 2007, 32, 289-297. [CrossRef]

106. Chintoh, A.F.; Mann, S.W.; Lam, L.; Lam, C.; Cohn, T.A.; Fletcher, P.J.; Nobrega, J.N.; Giacca, A.; Remington, G. Insulin resistance and decreased glucose-stimulated insulin secretion after acute olanzapine administration. J. Clin. Psychopharmacol. 2008, 28, 494-499. [CrossRef]

107. Chintoh, A.F.; Mann, S.W.; Lam, L.; Giacca, A.; Fletcher, P.; Nobrega, J.; Remington, G. Insulin resistance and secretion in vivo: Effects of different antipsychotics in an animal model. Schizophr. Res. 2009, 108, 127-133. [CrossRef]

108. Martins, P.J.; Haas, M.; Obici, S. Central nervous system delivery of the antipsychotic olanzapine induces hepatic insulin resistance. Diabetes 2010, 59, 2418-2425. [CrossRef]

109. Girault, E.M.; Alkemade, A.; Foppen, E.; Ackermans, M.T.; Fliers, E.; Kalsbeek, A. Acute peripheral but not central administration of olanzapine induces hyperglycemia associated with hepatic and extra-hepatic insulin resistance. PLOS ONE 2012, 7, e43244. [CrossRef]

110. Weston-Green, K.; Babic, I.; de Santis, M.; Pan, B.; Montgomery, M.K.; Mitchell, T.; Huang, X.F.; Nealon, J. Disrupted sphingolipid metabolism following acute clozapine and olanzapine administration. J. Biomed. Sci. 2018, 25, 40. [CrossRef]

111. Chintoh, A.F.; Mann, S.W.; Lam, T.K.; Giacca, A.; Remington, G. Insulin resistance following continuous, chronic olanzapine treatment: An animal model. Schizophr. Res. 2008, 104, 23-30. [CrossRef] [PubMed]

112. Ikegami, M.; Ikeda, H.; Ohashi, T.; Ohsawa, M.; Ishikawa, Y.; Kai, M.; Kamei, A.; Kamei, J. Olanzapine increases hepatic glucose production through the activation of hypothalamic adenosine $5^{\prime}$-monophosphate-activated protein kinase. Diabetes Obes. Metab. 2013, 15, 1128-1135. [CrossRef] [PubMed]

113. El-Seweidy, M.M.; Sadik, N.A.; Malek, M.M.; Amin, R.S. Chronic effects of clozapine administration on insulin resistance in rats: Evidence for adverse metabolic effects. Pathol. Res. Pract. 2014, 210, 5-9. [CrossRef] [PubMed]

114. Park, S.; Hong, S.M.; Lee, J.E.; Sung, S.R. Chlorpromazine exacerbates hepatic insulin sensitivity via attenuating insulin and leptin signaling pathway, while exercise partially reverses the adverse effects. Life Sci. 2007, 80, 2428-2435. [CrossRef]

115. Schmidt, R.H.; Jokinen, J.D.; Massey, V.L.; Falkner, K.C.; Shi, X.; Yin, X.; Zhang, X.; Beier, J.I.; Arteel, G.E. Olanzapine activates hepatic mammalian target of rapamycin: New mechanistic insight into metabolic dysregulation with atypical antipsychotic drugs. J. Pharmacol. Exp. Ther. 2013, 347, 126-135. [CrossRef]

116. Kapse, S.; Ando, H.; Fujiwara, Y.; Suzuki, C.; Ushijima, K.; Kitamura, H.; Hosohata, K.; Kotani, K.; Shimba, S.; Fujimura, A. Effect of a dosing-time on quetiapine-induced acute hyperglycemia in mice. J. Pharmacol. Sci. 2017, 133, 139-145. [CrossRef]

117. Liu, X.; Wu, Z.; Lian, J.; Hu, C.H.; Huang, X.F.; Deng, C. Time-dependent changes and potential mechanisms of glucose-lipid metabolic disorders associated with chronic clozapine or olanzapine treatment in rats. Sci. Rep. 2017, 7, 2762. [CrossRef]

118. Li, J.H.; Gautam, D.; Han, S.J.; Guettier, J.M.; Cui, Y.; Lu, H.; Deng, C.; O’Hare, J.; Jou, W.; Gavrilova, O.; et al. Hepatic muscarinic acetylcholine receptors are not critically involved in maintaining glucose homeostasis in mice. Diabetes 2009, 58, 2776-2787. [CrossRef]

119. Townsend, L.K.; Peppler, W.T.; Bush, N.D.; Wright, D.C. Obesity exacerbates the acute metabolic side effects of olanzapine. Psychoneuroendocrinology 2018, 88, 121-128. [CrossRef]

120. Ren, L.; Zhou, X.; Huang, X.; Wang, C.; Li, Y. The IRS/PI3K/Akt signaling pathway mediates olanzapine-induced hepatic insulin resistance in male rats. Life Sci. 2019, 217, 229-236. [CrossRef]

121. Mondelli, V.; Anacker, C.; Vernon, A.C.; Cattaneo, A.; Natesan, S.; Modo, M.; Dazzan, P.; Kapur, S.; Pariante, C.M. Haloperidol and olanzapine mediate metabolic abnormalities through different molecular pathways. Transl. Psychiatry 2013, 3, e208. [CrossRef] [PubMed]

122. Li, R.; Ou, J.; Li, L.; Yang, Y.; Zhao, J.; Wu, R. The Wnt Signaling Pathway Effector TCF7L2 Mediates Olanzapine-Induced Weight Gain and Insulin Resistance. Front. Pharmacol. 2018, 9, 379. [CrossRef] [PubMed] 
123. Boyda, H.N.; Procyshyn, R.M.; Tse, L.; Hawkes, E.; Jin, C.H.; Pang, C.C.; Honer, W.G.; Barr, A.M. Differential effects of 3 classes of antidiabetic drugs on olanzapine-induced glucose dysregulation and insulin resistance in female rats. J. Psychiatry Neurosci. 2012, 37, 407-415. [CrossRef] [PubMed]

124. Remington, G.J.; Teo, C.; Wilson, V.; Chintoh, A.; Guenette, M.; Ahsan, Z.; Giacca, A.; Hahn, M.K. Metformin attenuates olanzapine-induced hepatic, but not peripheral insulin resistance. J. Endocrinol. 2015, 227, 71-81. [CrossRef] [PubMed]

125. He, M.; Zhang, Q.; Deng, C.; Wang, H.; Huang, X.F. Olanzapine-activated AMPK signaling in the dorsal vagal complex is attenuated by histamine H1 receptor agonist in female rats. Endocrinology 2014, 155, 4895-4904. [CrossRef] [PubMed]

126. Ferno, J.; Varela, L.; Skrede, S.; Vazquez, M.J.; Nogueiras, R.; Dieguez, C.; Vidal-Puig, A.; Steen, V.M.; Lopez, M. Olanzapine-induced hyperphagia and weight gain associate with orexigenic hypothalamic neuropeptide signaling without concomitant AMPK phosphorylation. PLoS ONE 2011, 6, e20571. [CrossRef] [PubMed]

127. Girault, E.M.; Foppen, E.; Ackermans, M.T.; Fliers, E.; Kalsbeek, A. Central administration of an orexin receptor 1 antagonist prevents the stimulatory effect of Olanzapine on endogenous glucose production. Brain Res. 2013, 1527, 238-245. [CrossRef]

128. Anwar, I.J.; Miyata, K.; Zsombok, A. Brain stem as a target site for the metabolic side effects of olanzapine. J. Neurophysiol. 2016, 115, 1389-1398. [CrossRef]

129. Lam, C.K.; Chari, M.; Su, B.B.; Cheung, G.W.; Kokorovic, A.; Yang, C.S.; Wang, P.Y.; Lai, T.Y.; Lam, T.K. Activation of N-methyl-D-aspartate (NMDA) receptors in the dorsal vagal complex lowers glucose production. J. Biol. Chem. 2010, 285, 21913-21921. [CrossRef]

130. Lazzari, P.; Serra, V.; Marcello, S.; Pira, M.; Mastinu, A. Metabolic side effects induced by olanzapine treatment are neutralized by CB1 receptor antagonist compounds co-administration in female rats. Eur. Neuropsychopharmacol. 2017, 27, 667-678. [CrossRef]

131. Hahn, M.K.; Chintoh, A.; Remington, G.; Teo, C.; Mann, S.; Arenovich, T.; Fletcher, P.; Lam, L.; Nobrega, J.; Guenette, M.; et al. Effects of intracerebroventricular (ICV) olanzapine on insulin sensitivity and secretion in vivo: An animal model. Eur. Neuropsychopharmacol. 2014, 24, 448-458. [CrossRef] [PubMed]

132. Kowalchuk, C.; Teo, C.; Wilson, V.; Chintoh, A.; Lam, L.; Agarwal, S.M.; Giacca, A.; Remington, G.J.; Hahn, M.K. In male rats, the ability of central insulin to suppress glucose production is impaired by olanzapine, whereas glucose uptake is left intact. J. Psychiatry Neurosci. 2017, 42, 424-431. [CrossRef] [PubMed]

133. Boyda, H.N.; Ramos-Miguel, A.; Procyshyn, R.M.; Topfer, E.; Lant, N.; Choy, H.H.; Wong, R.; Li, L.; Pang, C.C.; Honer, W.G.; et al. Routine exercise ameliorates the metabolic side-effects of treatment with the atypical antipsychotic drug olanzapine in rats. Int. J. Neuropsychopharmacol. 2014, 17, 77-90. [CrossRef] [PubMed]

134. Lopez, M. Hypothalamic AMPK and energy balance. Eur. J. Clin. Investig. 2018, 48, e12996. [CrossRef] [PubMed]

135. Lynch, C.J.; Xu, Y.; Hajnal, A.; Salzberg, A.C.; Kawasawa, Y.I. RNA sequencing reveals a slow to fast muscle fiber type transition after olanzapine infusion in rats. PLoS ONE 2015, 10, e0123966. [CrossRef]

136. Weston-Green, K.; Huang, X.F.; Deng, C. Olanzapine treatment and metabolic dysfunction: A dose response study in female Sprague Dawley rats. Behav. Brain Res. 2011, 217, 337-346. [CrossRef]

137. Park, S.; Sang Mee, H.; Il Sung, A.; Sung Hoon, K. Olanzapine, not resperidone, exacerbates beta-cell function and mass in ovariectomized diabetic rats and estrogen replacement reverses them. J. Psychopharmacol. 2010, 24, 1105-1114. [CrossRef]

138. Coccurello, R.; Brina, D.; Caprioli, A.; Conti, R.; Ghirardi, O.; Schepis, F.; Moles, A. 30 days of continuous olanzapine infusion determines energy imbalance, glucose intolerance, insulin resistance, and dyslipidemia in mice. J. Clin. Psychopharmacol. 2009, 29, 576-583. [CrossRef]

139. Duttaroy, A.; Zimliki, C.L.; Gautam, D.; Cui, Y.; Mears, D.; Wess, J. Muscarinic stimulation of pancreatic insulin and glucagon release is abolished in $\mathrm{m} 3$ muscarinic acetylcholine receptor-deficient mice. Diabetes 2004, 53, 1714-1720. [CrossRef]

140. Guenette, M.D.; Giacca, A.; Hahn, M.; Teo, C.; Lam, L.; Chintoh, A.; Arenovich, T.; Remington, G. Atypical antipsychotics and effects of adrenergic and serotonergic receptor binding on insulin secretion in-vivo: An animal model. Schizophr. Res. 2013, 146, 162-169. [CrossRef]

141. Zhang, Q.; Zhu, Y.; Zhou, W.; Gao, L.; Yuan, L.; Han, X. Serotonin receptor 2C and insulin secretion. PLoS ONE 2013, 8, e54250. [CrossRef] [PubMed] 
142. Kim, K.; Oh, C.M.; Ohara-Imaizumi, M.; Park, S.; Namkung, J.; Yadav, V.K.; Tamarina, N.A.; Roe, M.W.; Philipson, L.H.; Karsenty, G.; et al. Functional role of serotonin in insulin secretion in a diet-induced insulin-resistant state. Endocrinology 2015, 156, 444-452. [CrossRef] [PubMed]

143. Ohara-Imaizumi, M.; Kim, H.; Yoshida, M.; Fujiwara, T.; Aoyagi, K.; Toyofuku, Y.; Nakamichi, Y.; Nishiwaki, C.; Okamura, T.; Uchida, T.; et al. Serotonin regulates glucose-stimulated insulin secretion from pancreatic beta cells during pregnancy. Proc. Natl. Acad. Sci. USA 2013, 110, 19420-19425. [CrossRef] [PubMed]

144. Hahn, M.; Chintoh, A.; Giacca, A.; Xu, L.; Lam, L.; Mann, S.; Fletcher, P.; Guenette, M.; Cohn, T.; Wolever, T.; et al. Atypical antipsychotics and effects of muscarinic, serotonergic, dopaminergic and histaminergic receptor binding on insulin secretion in vivo: An animal model. Schizophr. Res. 2011, 131, 90-95. [CrossRef]

145. Shivaprasad, C.; Kalra, S. Bromocriptine in type 2 diabetes mellitus. Indian J. Endocrinol. Metab. 2011, 15, S17-S24. [CrossRef]

146. Smith, G.C.; Vickers, M.H.; Cognard, E.; Shepherd, P.R. Clozapine and quetiapine acutely reduce glucagon-like peptide-1 production and increase glucagon release in obese rats: Implications for glucose metabolism and food choice behaviour. Schizophr. Res. 2009, 115, 30-40. [CrossRef]

147. Hsu, B.R.; Fu, S.H. GLP-1 receptor agonist exenatide restores atypical antipsychotic clozapine treatment-associated glucose dysregulation and damage of pancreatic islet beta cells in mice. Toxicol. Rep. 2016, 3, 458-463. [CrossRef]

148. Nagata, M.; Kimura, Y.; Ishiwata, Y.; Takahashi, H.; Yasuhara, M. Clozapine-Induced Acute Hyperglycemia Is Accompanied with Elevated Serum Concentrations of Adrenaline and Glucagon in Rats. Biol. Pharm. Bull. 2018, 41, 1286-1290. [CrossRef]

149. Smith, G.C.; McEwen, H.; Steinberg, J.D.; Shepherd, P.R. The activation of the Akt/PKB signalling pathway in the brains of clozapine-exposed rats is linked to hyperinsulinemia and not a direct drug effect. Psychopharmacology 2014, 231, 4553-4560. [CrossRef]

150. Swathy, B.; Banerjee, M. Understanding epigenetics of schizophrenia in the backdrop of its antipsychotic drug therapy. Epigenomics 2017, 9, 721-736. [CrossRef]

151. Zhang, J.P.; Lencz, T.; Zhang, R.X.; Nitta, M.; Maayan, L.; John, M.; Robinson, D.G.; Fleischhacker, W.W.; Kahn, R.S.; Ophoff, R.A.; et al. Pharmacogenetic Associations of Antipsychotic Drug-Related Weight Gain: A Systematic Review and Meta-analysis. Schizophr. Bull. 2016, 42, 1418-1437. [CrossRef] [PubMed]

152. Shams, T.A.; Muller, D.J. Antipsychotic induced weight gain: Genetics, epigenetics, and biomarkers reviewed. Curr Psychiatry Rep. 2014, 16, 473. [CrossRef] [PubMed]

153. Burghardt, K.J.; Seyoum, B.; Dass, S.E.; Sanders, E.; Mallisho, A.; Yi, Z. Association of Protein Kinase B (AKT) DNA Hypermethylation with Maintenance Atypical Antipsychotic Treatment in Patients with Bipolar Disorder. Pharmacotherapy 2018, 38, 428-435. [CrossRef] [PubMed]

154. Emamian, E.S.; Hall, D.; Birnbaum, M.J.; Karayiorgou, M.; Gogos, J.A. Convergent evidence for impaired AKT1-GSK3beta signaling in schizophrenia. Nat. Genet. 2004, 36, 131-137. [CrossRef]

155. Moons, T.; De Hert, M.; Kenis, G.; Viechtbauer, W.; van Os, J.; Gohlke, H.; Claes, S.; van Winkel, R. No association between genetic or epigenetic variation in insulin growth factors and antipsychotic-induced metabolic disturbances in a cross-sectional sample. Pharmacogenomics 2014, 15, 951-962. [CrossRef]

156. Brandl, E.J.; Tiwari, A.K.; Lett, T.A.; Shaikh, S.A.; Lieberman, J.A.; Meltzer, H.Y.; Kennedy, J.L.; Muller, D.J. Exploratory study on association of genetic variation in TBC1D1 with antipsychotic-induced weight gain. Hum. Psychopharmacol. 2013, 28, 183-187. [CrossRef]

157. Szekeres, F.; Chadt, A.; Tom, R.Z.; Deshmukh, A.S.; Chibalin, A.V.; Bjornholm, M.; Al-Hasani, H.; Zierath, J.R. The Rab-GTPase-activating protein TBC1D1 regulates skeletal muscle glucose metabolism. Am. J. Physiol. Endocrinol. Metab. 2012, 303, E524-E533. [CrossRef]

158. Ono, S.; Suzuki, Y.; Fukui, N.; Sugai, T.; Watanabe, J.; Tsuneyama, N.; Someya, T. Association between the GIPR gene and the insulin level after glucose loading in schizophrenia patients treated with olanzapine. Pharm. J. 2012, 12, 507-512. [CrossRef]

159. Larsen, J.R.; Vedtofte, L.; Jakobsen, M.S.L.; Jespersen, H.R.; Jakobsen, M.I.; Svensson, C.K.; Koyuncu, K.; Schjerning, O.; Oturai, P.S.; Kjaer, A.; et al. Effect of Liraglutide Treatment on Prediabetes and Overweight or Obesity in Clozapine- or Olanzapine-Treated Patients With Schizophrenia Spectrum Disorder: A Randomized Clinical Trial. JAMA Psychiatry 2017, 74, 719-728. [CrossRef] 
160. Siskind, D.; Hahn, M.; Correll, C.U.; Fink-Jensen, A.; Russell, A.W.; Bak, N.; Broberg, B.V.; Larsen, J.; Ishoy, P.L.; Vilsboll, T.; et al. Glucagon-like peptide-1 receptor agonists for antipsychotic-associated cardio-metabolic risk factors: A systematic review and individual participant data meta-analysis. Diabetes Obes. Metab. 2019, 21, 293-302. [CrossRef]

161. Brandl, E.J.; Tiwari, A.K.; Chowdhury, N.I.; Zai, C.C.; Lieberman, J.A.; Meltzer, H.Y.; Kennedy, J.L.; Muller, D.J. Genetic variation in the GCG and in the GLP1R genes and antipsychotic-induced weight gain. Pharmacogenomics 2014, 15, 423-431. [CrossRef] [PubMed]

162. Ramsey, T.L.; Brennan, M.D. Glucagon-like peptide 1 receptor (GLP1R) haplotypes correlate with altered response to multiple antipsychotics in the CATIE trial. Schizophr. Res. 2014, 160, 73-79. [CrossRef] [PubMed]

163. Ramsey, T.L.; Liu, Q.; Massey, B.W.; Brennan, M.D. Genotypic variation in the SV2C gene impacts response to atypical antipsychotics the CATIE study. Schizophr. Res. 2013, 149, 21-25. [CrossRef] [PubMed]

164. Gunes, A.; Melkersson, K.I.; Scordo, M.G.; Dahl, M.L. Association between HTR2C and HTR2A polymorphisms and metabolic abnormalities in patients treated with olanzapine or clozapine. J. Clin. Psychopharmacol. 2009, 29, 65-68. [CrossRef]

165. Burghardt, K.J.; Goodrich, J.M.; Dolinoy, D.C.; Ellingrod, V.L. Gene-specific DNA methylation may mediate atypical antipsychotic-induced insulin resistance. Bipolar Disord. 2016, 18, 423-432. [CrossRef]

166. Malhotra, A.K.; Correll, C.U.; Chowdhury, N.I.; Muller, D.J.; Gregersen, P.K.; Lee, A.T.; Tiwari, A.K.; Kane, J.M.; Fleischhacker, W.W.; Kahn, R.S.; et al. Association between common variants near the melanocortin 4 receptor gene and severe antipsychotic drug-induced weight gain. Arch. Gen. Psychiatry 2012, 69, 904-912. [CrossRef]

167. Mulder, H.; Franke, B.; van der-Beek van der, A.A.; Arends, J.; Wilmink, F.W.; Scheffer, H.; Egberts, A.C. The association between HTR2C gene polymorphisms and the metabolic syndrome in patients with schizophrenia. J. Clin. Psychopharmacol. 2007, 27, 338-343. [CrossRef]

168. Bai, Y.M.; Chen, T.T.; Liou, Y.J.; Hong, C.J.; Tsai, S.J. Association between HTR2C polymorphisms and metabolic syndrome in patients with schizophrenia treated with atypical antipsychotics. Schizophr. Res. 2011, 125, 179-186. [CrossRef]

169. Puangpetch, A.; Unaharassamee, W.; Jiratjintana, N.; Koomdee, N.; Sukasem, C. Genetic polymorphisms of HTR2C, LEP and LEPR on metabolic syndromes in patients treated with atypical antipsychotic drugs. J. Pharm. Pharmacol. 2018, 70, 536-542. [CrossRef]

170. Crespo-Facorro, B.; Prieto, C.; Sainz, J. Altered gene expression in antipsychotic-induced weight gain. NPJ Schizophr. 2019, 5, 7. [CrossRef]

171. Mitjans, M.; Catalan, R.; Vazquez, M.; Gonzalez-Rodriguez, A.; Penades, R.; Pons, A.; Massana, G.; Munro, J.; Arranz, M.J.; Arias, B. Hypothalamic-pituitary-adrenal system, neurotrophic factors and clozapine response: Association with FKBP5 and NTRK2 genes. Pharmacogenet. Genom. 2015, 25, 274-277. [CrossRef] [PubMed]

172. Beveridge, N.J.; Cairns, M.J. MicroRNA dysregulation in schizophrenia. Neurobiol. Dis. 2012, 46, $263-271$. [CrossRef] [PubMed]

173. Shi, S.; Leites, C.; He, D.; Schwartz, D.; Moy, W.; Shi, J.; Duan, J. MicroRNA-9 and microRNA-326 regulate human dopamine D2 receptor expression, and the microRNA-mediated expression regulation is altered by a genetic variant. J. Biol. Chem. 2014, 289, 13434-13444. [CrossRef] [PubMed]

174. He, K.; Guo, C.; He, L.; Shi, Y. MiRNAs of peripheral blood as the biomarker of schizophrenia. Hereditas 2018, 155, 9. [CrossRef] [PubMed]

175. Chen, S.D.; Sun, X.Y.; Niu, W.; Kong, L.M.; He, M.J.; Fan, H.M.; Li, W.S.; Zhong, A.F.; Zhang, L.Y.; Lu, J. A preliminary analysis of microRNA-21 expression alteration after antipsychotic treatment in patients with schizophrenia. Psychiatry Res. 2016, 244, 324-332. [CrossRef]

(C) 2019 by the authors. Licensee MDPI, Basel, Switzerland. This article is an open access article distributed under the terms and conditions of the Creative Commons Attribution (CC BY) license (http://creativecommons.org/licenses/by/4.0/). 